\title{
ADDITIONS TO THE DISTRIBUTION ATLAS OF VASCULAR PLANTS OF HUNGARY
}

\author{
Attila Rigó \\ Department of Botany, Hungarian Natural History Museum \\ H-1431 Budapest, Pf. 137, Hungary; rattila@outlook.com
}

Rigó, A. (2019): Additions to the Distribution atlas of vascular plants of Hungary. - Studia bot. bung. 50(1): 185-224.

\begin{abstract}
This paper presents additions to the Distribution atlas of vascular plants of Hungary with 661 new occurrence records for 497 taxa from 49 CEU grid cells. The new data are from the territory of Hungary, mainly from Budapest and its surroundings and the Danube and its tributaries. The second confirmed occurrence of Allium ursinum in the Pilis Mts, the confirmed occurrence of Ceratocephala testiculata in Budapest, the two new localities for Astragalus asper, the two ruderal localities for Atriplex littoralis, the new occurrence record for Lindernia procumbens near Göd, the occurrence of Salvinia molesta in Dunaalmás, Physalis peruviana and Silybum marianum in Budapest, and Azolla filiculoides at Dunaszeg are the most significant records presented in the paper.
\end{abstract}

Key words: flora mapping, occurrence record, adventive plants, Ceratocephala testiculata

\section{INTRODUCTION}

The development of Hungarian field botany in the 21th century enabled Hungarian botanists to prepare a comprehensive distribution atlas for the vascular plants of Hungary. The field research was carried out with standard methodology (KIRÁLY et al. 2003). As a result of the process, the Distribution atlas of vascular plants of Hungary (BARTHA et al. 2015) was published. Since then a couple of articles have been published to explicitly contribute to the atlas (TAKÁcs et al. 2016, MolnÁr et al. 2016, 2017, 2018, Kevey 2017, 2018, Csiky et al. 2017, 2018) and to have additions to the atlas as well (BARINA et al. 2015, TAKÁcs et al. 2016, PAPP et al. 2016, Mesterházy et al. 2017, Csiky et al. 2017, MATUs et al. 2018, SCHMid et al. 2018).

The present paper fits into the series with new occurrence data from mainly the surroundings of Budapest (primarily Budakalász and Üröm). Additional records are mainly from the shores of the Danube and its tributaries. Most of the data refers to common and widespread taxa. Beside these, a significant amount of the data comes from urban and ruderal areas. 


\section{MATERIAL AND METHODS}

For the last 3 years (2016-2018) I spent a lot of time with field botany, within that period, a great amount of data has been gathered. A small part of the gathered occurrence records seemed new. The occurrence records published in this article are new to the given CEU grid cells according to BARTHA et al. (2015).

EOV $1: 10,000$ topographic map of Hungary and OpenStreetMap were used to provide the geographic names. For geographic names that have no English equivalent I used the Hungarian name put between quotation marks. The taxa are listed in alphabetical order, the pattern of the given information is the following: taxon name - locality (year of the first discovery by the author) [CEU grid cell]. If there are more than one new occurrence record, the records are listed by the code of the CEU grid cell in ascending order. The description of the occurrence data is more specified when the species is rare or only found in a clearly defined area. The collected specimens are deposited in the herbarium of the Hungarian Natural History Museum, Botanical Department (BP).

Nomenclature follows KirÁly (2009) and The Plant List (2013) website in the case of the taxa which, are not included in the above work. For the identification of species KIRÁLY (2009) was used.

\section{RESULTS}

Acer platanoides L. - Pest county, Pilisborosjenő, Pilis Mts, frequent on 'Nagy-Kevély' (2018) [8379.4].

Acer saccharinum L. - Pest county, Veresegyház, frequent on the eastern shore of 'Pamut-tó', subspontaneous (2018) [8381.4]; Budapest IX, young specimens on the rocky shore of the Danube, near 'Petőfi híd', subspontaneous (2018) [8580.1].

Achillea asplenifolia Vent. - Budapest III, 'Mocsáros', in meadow (2017) [8480.1].

Achillea distans Waldst. \& Kit. ex Willd. - Pest county, Pomáz, Visegrád Mts, 'Mesélö-hegy', frequent in open oak forests and at forest margins (2017) [8380.1].

Achillea pannonica Scheele - Pest county, Budakalász, Pilis Mts, 'Monalovac', south of the quarry, in dry grassland (2017) [8380.3].

Achillea setacea Waldst. \& Kit. - Pest county, Üröm, Buda Mts, southern slope of 'Róka-hegy', in rocky grassland (2017) [8480.1].

Acinos arvensis (Lam.) Dandy - Pest county, Budakalász, Pilis Mts, 'Monalovac', southwest of the quarry, in forest-grassland mosaic (2017) [8380.3].

Aegilops cylindrica Host - Pest county, Pilisborosjenő, 'Kőfuvaros út', alongside the road (2016) [8379.4]; Pest county, Üröm, Buda Mts, southern slope of 'Róka-hegy', sporadic in rocky grassland (2018) [8480.1]. 
Aesculus hippocastanum L. - Pest county, Pomáz, Visegrád Mts, 'Csikóvár', 'Tó-lak', in oak forest (2018) [8379.2].

Agropyron cristatum (L.) Gaertn. - Pest county, Dunakeszi, sporadic on the western side of the hill of the Greek Catholic cemetery, in sand steppe (2018) [8380.4].

Agrostis stolonifera L. - Pest county, Szentendre, on the stony shore of the Danube near 'Duna korzó' (2017) [8380.1].

Ajuga genevensis L. - Pest county, Göd, in the area between the BudapestSzob railway line and 'Összekötő út' (bikeway), frequent in mesophilous sandy grassland (2018) [8380.2].

Ajuga reptans L. - Pest county, Pomáz, Visegrád Mts, 'Kö-hegy', frequent in oak-hornbeam forest (2016) [8380.1].

Albizia julibrissin Durazz. - Budapest XI, 'Villányi út', near Buda Arboretum, alongside the tram rail, in fissure, one young specimen, subspontaneous (2018) [8580.1].

Alisma gramineum Lej. - Győr-Moson-Sopron county, Dunaszeg, few terrestrial specimens on the shore of 'Mosoni-Duna', on exposed mud (2018) [8271.1]. Alliaria petiolata (M. Bieb.) Cavara \& Grande - Pest county, Pomáz, Visegrád Mts, 'Mesélö-hegy' and 'Kő-hegy', frequent in forests (2017) [8380.1]; Budapest XI, 'Gellért-hegy', frequent in forests, on disturbed shady grounds and in fissures (2016) [8580.1].

Allium moschatum L. - Pest county, Üröm, Buda Mts, 'Róka-hegy', in dry grasslands (2016) [8480.1].

Allium scorodoprasum L. - Pest county, Pilisszentkereszt, Pilis Mts, 'NagyBodzás-hegy', frequent in clearings of oak-ash forest (2017) [8279.3]; Pest county, Pomáz, Visegrád Mts, 'Mesélö-hegy', in forest-grassland mosaic (2017) [8380.1]; Budapest III, 'Mocsáros', in mesic grassland (2017) [8480.1].

Allium ursinum L. - Pest county, Pilisszentkereszt, Pilis Mts, on the northern slope of 'Pilis-tetö', very few specimens in juvenile beech forest (2017) [8379.1]. According to the atlas not confirmed since 1990 in that grid cell after KeveY (1978). The closest and the only proved occurrence from the Pilis Mts is from 'Csobánkai-nyereg' in grid cell 8379.4 (BARINA 2008).

Alnus glutinosa (L.) Gaertn. - Pest county, Szentendre, alongside 'Bükköspatak' (2017) [8380.1].

Alopecurus myosuroides Huds. - Budapest XIII, 'Árpád híd', some specimens in ruderal vegetation (2018) [8480.3].

Althaea officinalis L. - Budapest III, 'Mocsáros', in wet grasslands [8480.1]; Budapest III, on the rocky shore of the Danube near 'Hajógyári-sziget' (2018) [8480.3]. 
Amaranthus albus L. - Pest county, Szentendre, in the bed of the Danube near 'Papsziget', in mud vegetation (2018) [8380.2]; Budapest XI, 'Villányi út', frequent alongside the tram rails (2018) [8580.1].

Amaranthus blitoides S. Watson - Budapest XIII, 'Dózsa György út', in construction site, on bare soil (2018) [8480.3].

Amaranthus blitum L. - Pest county, Budakalász, in the bed of the Danube in front of 'Lupa-sziget', in mud vegetation (2018) [8380.4]; Budapest V, 'Szalay utca', in fissures (2018) [8480.3].

Amaranthus crispus (Lesp. \& Thévenau) A. Terracc. - Győr-Moson-Sopron county, Kimle, 'Fő út', alongside the road (2018) [8170.3].

Amaranthus deflexus L. - Komárom-Esztergom county, Dunaalmás, frequent alongside roads (2017) [8276.3].

Amaranthus patulus Bertol. - Budapest I, about $301-1.5 \mathrm{~m}$ tall specimens on the rocky shore of the Danube near 'Batthyány tér', subspontaneous (2018) [8480.3]; Budapest XI, 'Nándorfejérvári út', in fissure, a single specimen, subspontaneous (2018) [8580.1].

Amaranthus powellii S. Watson - Pest county, Budakalász, near the football pitch, on disturbed ground (2016) [8380.3]; Pest county, Solymár, north of 'ranyhegyi-patak', alongside gravel roads, on the margins of arable fields (2017) [8479.2]; Budapest XI, on the rocky shore of the Danube near 'Petőfi híd' (2018) [8580.1]; Budapest XXIII, in the territory of 'Soroksári Kísérleti Üzem és Tangazdaság', frequent on arable fields (2018) [8680.2].

Amygdalus communis L. - Pest county, Üröm, Buda Mts, southern slope of 'Róka-hegy', some solitaire trees, subspontaneous or planted (2017) [8480.1].

Anthemis austriaca Jacq. - Budapest XXIII, in the territory of 'Soroksári Kísérleti Üzem és Tangazdaság', on sand, as a weed (2018) [8680.2].

Anthemis ruthenica L. - Budapest XIII, 'Róbert Károly körút', in ruderal vegetation (2018) [8480.3]; Budapest XI, 'Dombóvári út', next to 'Rákóczi híd', in ruderal tall-herb vegetation (2016) [8580.1].

Anthericum ramosum L. - Pest county, Üröm, Buda Mts, southern slope of 'Róka-hegy', in rocky grassland (2016) [8480.1].

Anthriscus cerefolium (L.) Hoffm. - Pest county, Pomáz, Visegrád Mts, 'Mesélö-hegy', in nitrophilous places (2017) [8380.1].

Anthyllis vulneraria L. subsp. polyphylla (Kit.) Nyman. - Pest county, Üröm, Buda Mts, southern slope of 'Róka-hegy', in rocky grassland (2016) [8480.1].

Apera spica-venti (L.) P. Beauv. - Budapest III, at 'Szentlélek tér' suburban railway station, at the end of platform 'A', in ruderal vegetation (2018) [8480.3].

Aquilegia vulgaris L. - Budapest III, 'Mocsáros', near 'Nádszál utca', some specimens in mesic grassland, probably subspontaneous (2017) [8480.1]. 
Arabidopsis thaliana (L.) Heynh. - Pest county, Pomáz, frequent in grasslands and on disturbed grounds (2016) [8380.1]; Budapest XXIII, 'Telefondülő út', in the territory of 'Soroksári Kísérleti Üzem és Tangazdaság', on sandy arable fields, as a weed (2018) [8680.2]; Bács-Kiskun county, Tiszaug, frequent on disturbed grounds and grasslands (2016) [9186.2].

Arabis glabra (L.) Bernh. - Pest county, Pomáz, Visegrád Mts, 'Mesélő-hegy' and 'Kö-hegy', in open forests and at forest margins (2016) [8380.1].

Arabis hirsuta (L.) Scop. - Pest county, Üröm, Buda Mts, 'Róka-hegy', in rocky grassland (2017) [8480.1].

Artemisia pontica L. - Budapest X, 'Kőbányai út', a great polycormon on disturbed ground alongside the road (2018) [8580.2].

Asarum europaeum L. - Budapest II, Buda Mts, 'Látó-hegy', frequent in forests (2016) [8480.3].

Astragalus asper Wulfen - Pest county, Fót, Gödöllő Hills, west of 'FótiSomlyó', on sandy disturbed ground, rare (2018) [8381.3]; Budapest XXIII, in the territory of 'Soroksári Kísérleti Üzem és Tangazdaság', relatively frequent on long abandoned arable field, on sand (2018) [8680.2]. There are two herbarium sheets from 'Soroksár' in BP, one from 1888, (BP, 190678), the other from 1997 (BP, 472894)

Astragalus glycyphyllos L. - Budapest XXIII, between M5 highway and 'Szélső utca', on sandy wasteland (2017) [8581.3].

Atriplex littoralis L. - Pest county, Pilisborosjenő, 'Fő utca', few specimens along the road (2018) [8379.4]; Budapest III, 'Táncsics Mihály utca', few specimens in fissures (2018) [8380.3].

Atriplex patula L. - Pest county, Vác, Cserhát Mts, east of 'Bükkös-hegy', in grasslands (2017) [8281.1]; Pest county, Piliscsaba, 'Vasút utca', near 'Piliscsaba' railway station, in ruderal places (2018) [8378.4]; Pest county, Érd, 'Érdi magaspart', in grasslands and shrubland margins (2017) [8679.4].

Atriplex prostrata Boucher - Pest county, Budakalász, in the bed of the Danube, opposite 'Lupa-sziget', in mud vegetation (2018) [8380.4]; Budapest III, 'Mocsáros', sporadic in meadows (2017) [8480.1].

Atriplex sagittata Borkh. - Pest county, Vác, Cserhát Mts, at the margins of arable fields near Rád (2017) [8281.1].

Aurinia saxatilis (L.) Desv. - Budapest XI, on the north-eastern side of 'Gellért-hegy', one single specimen on the eastern stone wall (2018) [8580.1].

Azolla filiculoides Lam. - Györ-Moson-Sopron county, Dunaszeg, on the shore of 'Mosoni-Duna', some relatively big patches on exposed mud (2018) [8271.1].

Barbarea stricta Andrz. - Pest county, Budakalász, in periodical marshes in the riparian forest and in a wet grassland near the Danube (2017) [8380.4]. 
Barbarea vulgaris R. Br. - Pest county, Pomáz, Visegrád Mts, 'Zengő-völgy', in oak-hornbeam forest (2017) [8380.1].

Begonia cf. cucullata Willd. - Budapest XII, 'Gömb utca', in an inner courtyard, few specimens in fissures, subspontaneous (2018) [8480.3].

Berberis julianae C. K. Schneid. - Budapest II, Buda Mts, 'Kecske-hegy', alongside 'Szépvölgyi út', one specimen in a fissure, subspontaneous (2018) [8480.3].

Berula erecta (Huds.) Coville - Budapest III, 'Mocsáros', in channel 'Schäferárok', in slow-moving water (2017) [8480.1].

Betonica officinalis L. - Pest county, Pomáz, Visegrád Mts, 'Mesélő-hegy', frequent (2017) [8380.1]; Pest county, Üröm, Buda Mts, southern slope of 'Rókahegy', in rocky grassland (2016) [8480.1].

Bidens cernua L. - Budapest IV, in the dried bed of a small branch of the Danube between 'Palotai-sziget' and 'Népsziget', in mud vegetation (2018) [8480.1]; Budapest II, rare on the rocky shore of the Danube near 'Margit híd' (2018) [8480.3]; Pest county, Szigetszentmiklós, 'Soroksári-Duna', in slow-moving water, at the margin of reeds, rare (2017) [8680.2].

Bidens frondosa L. - Budapest III, frequent on the rocky shore of the Danube near 'Árpád híd' (2018) [8480.3]; Pest county, Szigetszentmiklós, 'SoroksáriDuna', in slow-moving water, sporadic at the margin of reeds (2017) [8680.2].

Bolboschoenus maritimus (L.) Palla - Budapest III, 'Mocsáros', in wet meadows (2017) [8480.1].

Bothriochloa ischaemum (L.) Keng - Pest county, Üröm, Buda Mts, southern slope of 'Róka-hegy', in rocky grassland (2016) [8480.1].

Brachypodium sylvaticum (Huds.) P. Beauv. - Budapest III, 'Mocsáros', alongside channel 'Schäfer-árok' and in forests (2017) [8480.1].

Brassica $\times$ napus L. - Budapest XIII, 'Árpád híd', in ruderal vegetation (2018) [8480.3].

Brassica rapa L. subsp. rapa - Budapest XXIII, in the territory of 'Soroksári Kísérleti Üzem és Tangazdaság', frequent on sandy meadow, subspontaneous (2018) [8680.2].

Brassica rapa L. subsp. oleifera (DC.) Metzg. - Pest county, Göd, 'Honvéd sor', along the railway, few specimens alongside the road, on sand (2018) [8280.4]; Budapest III, 'Ország út', few specimens alongside the road (2018) [8380.3].

Bromus arvensis L. - Pest county, Szentendre, Visegrád Mts, 'Izbég', in loessy grassland (2018) [8380.1].

Bromus erectus Huds. - Pest county, Solymár, Buda Mts, 'Kálvária-hegy', sporadic in forest-grassland mosaic (2018) [8479.2]; Pest county, Üröm, Buda Mts, southern slope of 'Róka-hegy', frequent in rocky grassland (2017) [8480.1]. 
Broussonetia papyrifera (L.) Vent. - Budapest II, some young specimens on the rocky shore of the Danube near 'Zsigmond tér', subspontaneous (2018) [8480.3].

Bryonia alba L. - Pest county, Budakalász, 'Árok utca', in hedge (2018) [8380.3].

Buglossoides arvensis (L.) I. M. Johnston - Pest county, Pomáz, Visegrád Mts, 'Kő-hegy', in grasslands (2016) [8380.1]; Budapest II, Buda Mts, 'Kálváriahegy', in grasslands and alongside forest roads (2016) [8479.2]; Budapest XXIII, Telefondűlỏ út, in the territory of 'Soroksári Kísérleti Üzem és Tangazdaság', on sandy arable fields, as a weed (2018) [8680.2].

Calendula officinalis L. - Pest county, Pilisborosjenő, 'Kőfuvaros út', alongside the road, few specimens, subspontaneous (2016) [8379.4].

Calepina irregularis (Asso) Thell. - Budapest III, 'Vonat utca', on the shore of 'Aranyhegyi-patak' (2018) [8480.1].

Camelina microcarpa Andrz. ex DC. - Pest county, Pomáz, Visegrád Mts, 'Kö-hegy', some specimens in open siliceous grassland near 'Petőfi-pihenö' (2017) [8380.1]; Fejér county, Vértesacsa, on a farm, as a weed (2018) [8677.2].

Cannabis sativa L. subsp. spontanea Serebr. - Budapest III, at 'Szentlélek tér' suburban railway station, at the end of platform 'A', in ruderal vegetation (2016) [8480.3].

Capsella bursa-pastoris (L.) Medik. - Bács-Kiskun county, Tiszaug, frequent on disturbed grounds and in grasslands (2016) [9186.2].

Cardamine hirsuta L. - Pest county, Budakalász, 'János utca', in garden, on disturbed ground (2016) [8380.3]; Budapest VIII, 'Könyves Kálmán körút', in the front yard of the Botanical Department of the Hungarian Natural History Museum (2018) [8580.2].

Cardamine pratensis L. s. 1. - Györ-Moson-Sopron county, Dunaszeg, on the shore of 'Mosoni-Duna', on exposed mud (2018) [8271.1]; Pest county, Budakalász, relatively frequent in periodical marshes in the riparian forest and in a wet grassland near the Danube (2017) [8380.4].

Cardaminopsis arenosa (L.) Hayek - Pest county, Pomáz, Visegrád Mts, 'Köhegy', frequent in forests and rocky grasslands (2016) [8380.1].

Carduus nutans L. - Pest county, Budakalász, Pilis Mts, 'Monalovac', southwest of the quarry, in open thermophilous oak forest (2017) [8380.3].

Carex acuta L. - Pest county, Budakalász, in periodical marshes in the riparian forest (2018) [8380.4]; Budapest X, in 'Felsőrákosi rétek TT' protected area, south of 'Rákos-patak', in the dried border of a small lake, on exposed mud (2018) [8581.1].

Carex distans L. - Pest county, Budakalász, 'János utca', in garden, on disturbed ground (2018) [8380.3]. 
Carex divulsa Stokes subsp. leersii (Kneucker) W. Koch - Pest county, Pilisszentkereszt, Pilis Mts, 'Dera-szurdok', alongside 'Dera-patak' (2017) [8379.1]; Pest county, Budakalász, Pilis Mts, 'Ezüst-Kevély', in oak forest (2017) [8379.4]; Szentendre, Visegrád Mts, 'Kis-Kö-hegy', in mixed oak forest (2017) [8380.1].

Carex elata All. - Pest county, Pomáz, Visegrád Mts, 'Csikóvár', 'Tó-lak', at the western swamp, in tall sedge community (2018) [8379.2].

Carex flacca Schreb. - Pest county, Veresegyház, on the eastern shore of 'Pamut-tó', at damp places (2018) [8381.4]; Budapest III, Mocsáros, in wet grasslands and meadows (2017) [8480.1].

Carex flava L. - Budapest XXIII, between M5 highway and 'Búzakéve utca', in tall sedge community (2017) [8581.3].

Carex hirta L. - Budapest III, 'Mocsáros', in wet grasslands and meadows (2017) [8480.1].

Carex liparicarpos Gaudin - Pest county, Budakalász, Pilis Mts, 'Monalovac', frequent above the quarry, on rocky ground [8380.3]; Pest county, Üröm, Buda Mts, 'Róka-hegy', frequent in rocky grassland [8480.1].

Carex pairaei F. W. Schultz - Pest county, Pilisborosjenő, Pilis Mts, 'EzüstKevély', at the margin of acidofrequent oak forest (2016) [8379.4]; Pest county, Pomáz, Visegrád Mts, 'Kö-hegy', in forest-grassland mosaic (2016) [8380.1].

Carex panicea L. - Budapest III, 'Mocsáros', in wet grasslands and meadows (2017) [8480.1].

Carex pilosa Scop. - Pest county, Pomáz, Visegrád Mts, 'Kő-hegy', in mesotrophic deciduous forests (2016) [8380.1].

Carex praecox Schreb. - Jász-Nagykun-Szolnok county, Tiszakürt, on the Tisza floodplain, frequent on the embankment (2016) [9186.2].

Carex riparia Curtis - Pest county, Pomáz, Visegrád Mts, 'Csikóvár', 'Tólak', at the eastern swamp ('Csikóvári-tó'), in tall sedge community (2018) [8379.2]; Pest county, Budakalász, in periodical marshes in the riparian forest (2018) [8380.4].

Carex spicata Huds. - Pest county, Solymár, Buda Mts, 'Kálvária-hegy', in forest-grassland mosaic (2017) [8479.2]; Budapest VIII, 'Könyves Kálmán körút', in the front yard of the Botanical Department of the Hungarian Natural History Museum (2017) [8580.2].

Carex stenophylla Wahlenb. - Bács-Kiskun county, Tiszaug, east to the village, in saline grassland (2016) [9186.2].

Carex supina Willd. ex Wahlenb. - Pest county, Budakalász, Pilis Mts, 'Monalovac', in a shrubbing lawn (2017) [8380.3].

Carex tomentosa L. - Pest county, Budakalász, frequent in grasslands around the town (2017) [8380.3]. 
Carex vesicaria L. - Pest county, Budakalász, in periodical marshes in the riparian forest (2018) [8380.4].

Carex vulpina L. - Budapest III, 'Mocsáros', in wet grasslands and meadows (2017) [8480.1]; Bács-Kiskun county, Tiszaug, east of the village, in saline grassland, at mire (2016) [9186.2].

Catalpa bignonioides Walter - Budapest III, on the rocky shore of the Danube near 'Árpád híd', some young specimens, subspontaneous (2018) [8480.3].

Centaurea jacea L. subsp. angustifolia Gremli - Pest county, Pilisszentkereszt, Pilis Mts, 'Kakas-hegy', 'Három-forrás völgye', in forest clearing (2016) [8279.3]; Budapest III, 'Mocsáros', near 'Határ út', in mesic grassland (2017) [8480.1].

Centaurea stoebe L. - Pest county, Pomáz, Visegrád Mts, 'Mesélö-hegy', in forest-grassland mosaic (2017) [8380.1]; Pest county, Üröm, Buda Mts, southern slope of 'Róka-hegy', frequent in rocky grassland (2016) [8480.1].

Centaurium pulchellum (Sw.) Druce - Pest county, Veresegyház, on the eastern shore of 'Pamut-tó', at damp places alongside paths (2017) [8381.4].

Cerastium dubium (Bastard) Guépin - Bács-Kiskun county, Tiszaug, east of the village, in saline grasslands (2016) [9186.2].

Cerastium glutinosum Fr. - Pest county, Üröm, Buda Mts, southern slope of 'Róka-hegy', in rocky grassland (2017) [8480.1].

Cerastium semidecandrum L. - Budapest XXIII, in the territory of 'Soroksári Kísérleti Üzem és Tangazdaság', on sand, as a weed (2016) [8680.2].

Cerasus fruticosa (Pall.) Woronow - Pest county, Érd, 'Érdi magaspart', at oak forest margins (2017) [8679.4].

Cerasus mahaleb (L.) Mill. - Pest county, Üröm, Buda Mts, southern slope of 'Róka-hegy', in shrub (2017) [8480.1].

Cerasus vulgaris Mill. - Pest county, Üröm, Buda Mts, 'Róka-hegy', at the quarry (2018) [8480.1].

Ceratocephala testiculata (Crantz) Roth - Budapest XI, Villányi út, at tram station 'Tas Vezér utca', on disturbed ground, very few specimen (2018) [8580.1]. The atlas states that there are no data since 1950 on Ceratocephala testiculata in that grid cell. There are several old herbarium specimens from Budapest and Budaörs deposited in BP, but the locations are inaccurately described on the labels. The latest herbarium sheet from the same grid cell was collected in 1948 by Bánó, 'Sashegy deli oldala' (BP, 425526). There is a herbarium sheet from 1974 collected by Papp in 'Kissvábhegy' (BP, 370667), which is in the neighbouring grid cell (8480.3). SomLYAY et al. (2016) rediscovered the species in Budaörs ('Odvas-hegy' and 'Út-hegy').

Ceratophyllum demersum L. - Pest county, Szigetszentmiklós, 'SoroksáriDuna', in slow-moving water (2017) [8680.2]. 
Chaerophyllum bulbosum L. - Pest county, Pilisszentkereszt, Pilis Mts, on an old, ruined bridge over 'Mogyorós-patak', in disturbed place (2017) [8379.1]; Pest county, Szentendre, Visegrád Mts, 'Kis-Kö-hegy', at disturbed forest margins (2018) [8380.1].

Chaerophyllum temulum L. - Pest county, Pilisszántó, Pilis Mts, above 'Deraszurdok', in degraded, disturbed places alongside forest roads (2017) [8379.1]; Pest county, Pomáz, Pilis Mts, Visegrád Mts, 'Kő-hegy', in mesotrophic oak-hornbeam forest (2016) [8380.1]; Pest county, Budakalász, Pilis Mts, 'Ezüst-Kevély', in degraded oak forest near Sadove (2017) [8380.3].

Chamaecytisus austriacus (L.) Link - Pest county, Üröm, Buda Mts, southern slope of 'Róka-hegy', in rocky grassland (2016) [8480.1].

Chenopodium ambrosioides L. - Pest county, Budakalász, in the bed of the Danube, opposite 'Lupa-sziget', in mud vegetation (2018) [8380.4].

Chenopodium botrys L. - Budapest XIII, 'Visegrádi utca', in ruderal vegetation, one specimen (2018) [8480.3].

Chenopodium ficifolium Sm. - Pest county, Budakalász, in the bed of the Danube, opposite 'Lupa-sziget', in mud vegetation (2018) [8380.4].

Chenopodium glaucum L. - Pest county, Tahitótfalu, 'Szentendrei-sziget', on a farm, as a weed (2018) [8280.2]; Pest county, Szentendre, in the bed of the Danube near 'Duna korzó', in mud vegetation (2018) [8380.1]; Pest county, Budakalász, in the bed of the Danube, opposite 'Lupa-sziget', in mud vegetation (2018) [8380.4]; Budapest XI, on the rocky shore of the Danube near 'Petőfi híd' (2018) [8580.1].

Chenopodium polyspermum L. - Budapest IX, on the rocky shore of the Danube near 'Petőfi híd' (2018) [8580.1].

Chenopodium rubrum L. - Pest county, Szentendre, in the bed of the Danube near 'Duna korzó', in mud vegetation (2018) [8380.1].

Chenopodium urbicum L. - Pest county, Budakalász, in the bed of the Danube, opposite 'Lupa-sziget', in mud vegetation (2018) [8380.4].

Chenopodium vulvaria L. - Pest county, Budakalász, 'Budai út', sporadic in flower beds (2018) [8380.3]; Budapest III, 'Öszike utca', sporadic on disturbed grounds (2018) [8480.1].

Cirsium canum (L.) All. - Budapest III, 'Mocsáros', alongside channel 'Schäfer-árok' and in mesotrophic grasslands (2017) [8480.1].

Citrullus lanatus (Thunb.) Mansf. - Budapest V, some flowering specimens on the rocky shore of the Danube near 'Széchenyi rakpart', subspontaneous (2018) [8480.3]; Budapest XI, some flowering specimens on the rocky shore of the Danube, near 'Petöfi híd', subspontaneous (2018) [8580.1].

Cladium mariscus (L.) Pohl - Pest county, Göd, in the area between 'Sződrákosi-patak', 'Ilka-patak', and 'István utca', on the margin of Salix caprea 
scrub (2017) [8280.4]; Budapest XXIII, Soroksár, between highway M5 and 'Búzakéve utca', a great population in reed (2017) [8581.3].

Clematis recta L. - Pest county, Pomáz, Visegrád Mts, 'Mesélö-hegy', sporadic in open oak forest (2017) [8380.1].

Clinopodium vulgare L. - Pest county, Pilisborosjenő, Pilis Mts, 'EzüstKevély', in oak forest, alongside paths (2016) [8380.3].

Colutea arborescens L. - Pest county, Budakalász, Pilis Mts, 'Monalovac', southwest of the quarry, in thicket (2017) [8380.3]; Budapest IV, north of 'Megyeri-híd', along the embankment (2017) [8380.4].

Commelina communis L. - Budapest XI, 'Villányi út', alongside the tram rails, subspontaneous (2018) [8580.1]; Budapest VIII, 'Könyves Kálmán körút', alongside road, in ruderal vegetation, subspontaneous (2016) [8580.2].

Consolida orientalis (J. Gay) Schrödinger - Budapest XXIII, 'Telefondűlő út' in the territory of 'Soroksári Kísérleti Üzem és Tangazdaság', on sandy arable fields, as a weed (2018) [8680.2].

Convallaria majalis L. - Pest county, Pomáz, Pilis Mts, 'Mesélol-hegy', in mesotrophic deciduous forests (2017) [8380.1].

Convolvulus cantabrica L. - Pest county, Pilisborosjenő, Pilis Mts, 'NagyKevély', near the apex, sporadic in limestone grassland (2016) [8379.4]; Pest county, Üröm, Buda Mts, southern slope of 'Róka-hegy', sporadic in rocky grassland (2018) [8480.1].

Cornus mas L. - Budapest II, Buda Mts, 'Látó-hegy', frequent in forests (2016) [8480.3].

Corydalis cava L. - Budapest II, Buda Mts, 'Látó-hegy', frequent in mixed oak forest (2016) [8480.3].

Corydalis solida L. - Budapest II, Buda Mts, 'Látó-hegy', frequent in mixed oak forest (2016) [8480.3].

Cotoneaster horizontalis Decne. - Pest county, Üröm, Buda Mts, southern slope of 'Róka-hegy', one small bush growing in a limestone fissure, subspontaneous (2017) [8480.1].

Cotoneaster integerrimus Medik. - Budapest II, Buda Mts, 'Kálvária-hegy', small shrubs near the peak (2016) [8479.2].

Crepis biennis L. - Budapest III, 'Mocsáros', alongside channel 'Schäferárok' and on the wall of the amphitheatre (2017) [8480.1].

Crepis pulchra L. - Budapest IV, in 'Újpesti Homoktövis TT' protected area, in sand steppe (2018) [8380.4].

Crepis setosa Haller - Budapest XXIII, in the territory of 'Soroksári Kísérleti Üzem és Tangazdaság', on sand, as a weed (2018) [8680.2]. 
Crepis tectorum L. - Budapest III, 'Békásmegyer' suburban railway station, between rails (2017) [8480.1]; Budapest XXIII, in the territory of 'Soroksári Kísérleti Üzem és Tangazdaság', on sand, as a weed (2016) [8580.4].

Cruciata pedemontana (Bellardi) Ehrend. - Pest county, Budakalász, Pilis Mts, 'Monalovac', in shrubbing forest clearing (2017) [8380.3]; Bács-Kiskun county, Tiszaug, east of the village, in saline grassland (2016) [9186.2].

Crypsis schoenoides (L.) Lam. - Pest county, Budakalász, in the bed of the Danube, opposite 'Lupa-sziget', in mud vegetation, very rare (2018) [8380.4].

Cucumis sativus L. - Budapest III, on the rocky shore of the Danube near 'Árpád híd', some specimens, subspontaneous (2018) [8480.3].

Cucurbita maxima Duch. - Győr-Moson-Sopron county, Kimle; next to pumpkin plantation north of the settlement, some specimens growing subspontaneously on the forest margin (2018) [8170.3].

Cuscuta epithymum (L.) Nath. subsp. kotschyi (Des Moul.) Arcang. - Pest county, Üröm, Buda Mts, southern slope of 'Róka-hegy', in rocky grassland, parasitizing Dorycnium pentaphyllum Scop. (2018) [8480.1].

Cymbalaria muralis G. Gaertn., B. Mey. \& Scherb. - Budapest III, 'Mocsáros', on the wall of the amphitheatre (2016) [8480.1].

Cynoglossum hungaricum Simonk. - Budapest IV, in 'Újpesti Homoktövis TT', in open oak forest margin on sand (2017) [8380.4].

Cynoglossum officinale L. - Pest county, Pomáz, Visegrád Mts, 'Kö-hegy', in siliceous grasslands (2017) [8380.1].

Cyperus fuscus L. - Pest county, Szentendre, in the bed of the Danube near 'Duna korzó', in mud vegetation (2018) [8380.1]; Pest county, Veresegyház, on the sandy shore of 'Álom-hegyi víztározó' (2017) [8381.4]; Budapest III, 'Határ út', in dried concrete drainage canal, in fissures (2018) [8480.1]; Budapest IV, on the dried bed of a small branch of the Danube between 'Palotai-sziget' and 'Népsziget', in mud vegetation (2018) [8480.1].

Cyperus glomeratus L. - Budapest IV, in the bed of the Danube near 'Palotaisziget', in mud vegetation (2018) [8480.1]; Budapest II, on the rocky shore of the Danube near 'Zsigmond tér' (2018) [8480.3].

Cystopteris fragilis (L.) Bernh. - Pest county, Pomáz, Visegrád Mts, 'Mesélöhegy', rare in mesotrophic oak forest (2017) [8380.1].

Dactylis polygama Horv. - Komárom-Esztergom county, Pilisszentlélek (Esztergom), Pilis Mts, 'Nagy-Bodzás-hegy', frequent in deciduous forests (2017) [8279.3]; Pest county, Pomáz, Visegrád Mts, 'Mesélő-hegy', frequent in oak forest (2017) [8380.1].

Deschampsia cespitosa (L.) P. Beauv. - Pest county, Pilisszentkereszt, Pilis Mts, 'Nagy-Bodzás-hegy', in mesophilous oak forest (2017) [8279.3]; Budapest III, 'Mocsáros', alongside channel 'Schäfer-árok' (2017) [8480.1]. 
Descurainia sophia (L.) Webb - Budapest XXIII, in the territory of 'Soroksári Kísérleti Üzem és Tangazdaság', on sand, as a weed (2018) [8580.4].

Dianthus superbus L. - Budapest XXIII, in the Soroksár Botanical Garden, in natural Molinia meadow (2018) [8580.4]. The data was known (BogYÁnÉ \& KECSKÉs 1993), but is missing from the atlas.

Dichostylis micheliana (L.) Nees - Budapest IV, on the dried bed of a small branch of the Danube between 'Palotai-sziget' and 'Nép-sziget', in mud vegetation (2018) [8480.1].

Digitaria sanguinalis (L.) Scop. - Budapest XXIII, in the territory of 'Soroksári Kísérleti Üzem és Tangazdaság', on sand, as a weed (2016) [8680.2].

Dipsacus fullonum L. - Pest county, Budakalász, alongside road 11, frequent on wastelands (2018) [8380.3].

Draba nemorosa L. - Budapest XXIII, in the territory of 'Soroksári Kísérleti Üzem és Tangazdaság', on fallow field, on sand (2018) [8680.2].

Echinochloa crus-galli (L.) P. Beauv. - Pest county, Pilisszentkereszt, frequent in grasslands and on disturbed grounds around the village (2016) [8279.3].

Echium vulgare L. - Pest county, Budakalász, in grasslands and on disturbed grounds around the town (2017) [8380.3].

Elodea canadensis Michx. - Győr-Moson-Sopron county, Mosonmagyaróvár, in the water of 'Mosoni-Duna' (2018) [8169.2].

Epilobium hirsutum L. - Györ-Moson-Sopron county, Kimle, on the shore of a small branch of 'Mosoni-Duna' (2018) [8170.3]; Budapest III, 'Mocsáros', in mesic meadow (2017) [8480.1].

Equisetum palustre L. - Pest county, Solymár, alongside 'Aranyhegyi-patak', in reed (2017) [8479.2].

Equisetum ramosissimum Desf. - Pest county, Veresegyház, on the eastern shore of 'Pamut-tó', at damp places (2017) [8381.4].

Eragrostis minor Host - Budapest XIII, next to 'Árpád híd', in flower beds (2018) [8480.3]; Budapest V, 'Szalay utca', in fissures (2018) [8480.3]; Pest county, Tápiószőlős, on disturbed ground alongside roads (2017) [8785.1].

Eragrostis pilosa (L.) P. Beauv. - Pest county, Tahitótfalu, 'Szentendreisziget', on disturbed ground alongside roads (2018) [8280.2].

Erophila verna (L.) Chevall. - Pest county, Budakalász, 'Vasút sor', near the suburban railway station, on disturbed ground (2016) [8380.3].

Erysimum diffusum Ehrh. - Pest county, Üröm, Buda Mts, southern slope of 'Róka-hegy', in rocky grassland (2017) [8480.1].

Euonymus verrucosus Scop. - Pest county, Üröm, Buda Mts, 'Róka-hegy', frequent at the quarry (2018) [8480.1].

Euphorbia amygdaloides L. - Pest county, Budakalász, Pilis Mts, 'NagyKevély', frequent in forests (2016) [8380.3]. 
Euphorbia esula L. - Pest county, Budakalász, near 'Lupa-tó', alongside roads, at forest margins (2017) [8380.4]; Budapest III, 'Vonat utca', on the shore of 'Aranyhegyi-patak' (2017) [8480.1].

Euphorbia glareosa Pall. - Pest county, Üröm, Buda Mts, southern slope of 'Róka-hegy', in rocky grassland (2016) [8480.1].

Euphorbia helioscopia L. - Budapest XII, 'Gömb utca', in a parking lot, in ruderal vegetation (2018) [8480.3]; Budapest XXIII, 'Telefondülő út', in the territory of 'Soroksári Kísérleti Üzem és Tangazdaság', on sandy arable fields, as a weed (2018) [8680.2].

Euphorbia lathyris L. - Pest county, Budakalász, 'Posta köz', at construction site, few specimens growing on disturbed ground and in fissures, subspontaneous (2018) [8380.3]; Pest county, Fót, 'Fáy-sétány', few specimens growing on disturbed sandy ground, subspontaneous (2018) [8381.3].

Euphorbia maculata L. - Budapest III, 'Békásmegyer', frequent in fissures (2018) [8380.3]; Budapest III, 'Római Fürdo’', frequent in fissures (2018) [8480.1]; Budapest III, 'Óbuda' and Budapest XIII, frequent in flower beds and fissures (2018) [8480.3]; Budapest XIV, near tram station 'Kacsóh Pongrác út', in park, frequent (2018) [8480.4].

Euphorbia myrsinites L. - Pest county, Üröm, Buda Mts, southern slope of 'Róka-hegy', in rocky grassland, some specimens growing near gardens, subspontaneous (2017) [8480.1].

Euphorbia palustris L. - Budapest III, 'Mocsáros', sporadic in wet meadow (2017) [8480.1].

Euphorbia peplus L. - Pest county, Budakalász, frequent on disturbed grounds (2017) [8380.3].

Euphorbia seguieriana Neck. - Pest county, Budakalász, Pilis Mts, 'Monalovac', southwest of the quarry, in dry stony grassland (2017) [8380.3].

Euphorbia virgata Waldst. \& Kit. - Pest county, Göd, on the shore of 'Ilkapatak' and 'Sződrákosi-patak' (2018) [8280.4]; Pest county, Budakalász, 'Sport utca', near the football pitch, in uncharacteristic grassland (2016) [8380.3]; Pest county, Üröm, Buda Mts, southern slope of 'Róka-hegy', in rocky grassland (2017) [8480.1].

Fallopia $\times$ bohemica (Chrtek \& Chrtková) J. P. Bailey - Pest county, Budakalász, alongside 'Lupaszigeti utca' (2018) [8380.3].

Fallopia baldschuanica (Regel) Holub - Pest county, Szentendre, Visegrád Mts, 'Kis-Kö-hegy', on fences, in hedges (2018) [8380.1].

Fallopia dumetorum (L.) Holub - Budapest II, Buda Mts, 'Kálvária-hegy', in deciduous forest, climbing on trees (2016) [8479.2].

Festuca pallens Host - Pest county, Üröm, Buda Mts, southern slope of 'Róka-hegy', in rocky grassland (2017) [8480.1]. 
Festuca pseudovina Hack. - Budapest XXIII, in the territory of 'Soroksári Kísérleti Üzem és Tangazdaság', frequent on long abandoned arable field, on sand (2018) [8680.2].

Filago arvensis L. - Pest county, Pilisborosjenő, Pilis Mts, 'Ezüst-Kevély', at the margin of acidofrequent oak forest, on rocky slope (2016) [8380.3].

Filipendula ulmaria (L.) Maxim. - Pest county, Veresegyház, on the eastern shore of 'Pamut-tó', at the margin of the reed (2017) [8381.4].

Filipendula vulgaris Moench - Pest county, Budakalász, Pilis Mts, 'Monalovac', southwest of the quarry, in dry stony grassland (2017) [8380.3].

Fragaria vesca L. - Budapest III, 'Mocsáros', alongside channel 'Schäferárok' and at mesic forest margins (2017) [8480.1]; Jász-Nagykun-Szolnok county, Tiszakürt, in the Tiszakürt Arboretum, as a weed (2016) [9186.2].

Fragaria viridis Duchesne - Pest county, Pomáz, Visegrád Mts, 'Kö-hegy', in forests (2016) [8380.1]; Pest county, Budakalász, Pilis Mts, 'Monalovac', southwest of the quarry, on wasteland (2017) [8380.3].

Frangula alnus Mill. - Pest county, Pilisborosjenő, Pilis Mts, 'Köves-bérc', in open acidofrequent oak forest (2016) [8379.4]; Budapest III, 'Mocsáros', alongside channel 'Schäfer-árok' (2017) [8480.1].

Fraxinus ornus L. - Pest county, Üröm, Buda Mts, 'Róka-hegy', frequent at the quarry (2018) [8480.1].

Fumaria officinalis L. - Pest county, Pilisborosjenő, Pilis Mts, 'Nagy-Kevély', alongside the road next to dolomite grasslands (2016) [8379.4].

Fumaria vaillantii Loisel. - Pest county, Budakalász, 'Damjanich utca', in fissures (2016) [8380.3]; Budapest XI, 'Somlói út', in fissures (2018) [8580.1].

Gagea pratensis (Pers.) Dumort. - Pest county, Göd, 'Összekötő út' (bikeway), alongside the road (2018) [8380.2]; Pest county, Budakalász, Pilis Mts, 'Ajmanica fennsík' and 'Monalovac', frequent in grasslands and alongside forest roads (2016) [8380.3].

Gagea pusilla (F. W. Schmidt) Schult. \& Schult. f. - Pest county, Göd, in the area between the Budapest-Szob railway line and 'Összekötő út' (2018) (bikeway), in sand steppe [8380.2]; Pest county, Budakalász, Pilis Mts, 'Monalovac', frequent (2016) [8380.3]; Budapest II, Buda Mts, 'Látó-hegy', in mixed oak forest (2016) [8480.3].

Gagea villosa (M. Bieb.) Duby - Pest county, Budakalász, near 'Omszki-tó', on disturbed ground (2016) [8380.3].

Galeopsis pubescens Besser - Pest county, Pilisszentkereszt, Pilis Mts, 'Kakashegy', alongside wide forest road (2016) [8279.3].

Galinsoga ciliata Raf. S. F. Blake - Budapest V, 'Balaton utca', in front garden (2018) [8480.3]; Budapest XI, 'Bicskei utca', in fissures (2017) [8580.1]; Budapest 
VIII, 'Könyves Kálmán körút', in the back yard of the Botanical Department of the Hungarian Natural History Museum (2018) [8580.2].

Galium aparine L. - Pest county, Pomáz, Visegrád Mts, 'Kő-hegy' and 'Mesélö-hegy', frequent (2016) [8380.1].

Galium glaucum L. - Pest county, Pomáz, Visegrád Mts, 'Mesélő-hegy', in forest-grassland mosaic (2016) [8380.1]; Pest county, Üröm, Buda Mts, southern slope of 'Róka-hegy', in rocky grassland (2017) [8480.1].

Galium mollugo L. - Budapest III, 'Mocsáros', frequent in grasslands and disturbed places (2017) [8480.1].

Galium odoratum (L.) Scop. - Pest county, Csobánka, Pilis Mts, 'Kis-Kevély', frequent in oak-hornbeam forest (2017) [8379.4].

Galium palustre L. - Pest county, Budakalász, in periodical marshes in the riparian forest (2017) [8380.4]; Budapest III, on the rocky shore of the Danube near 'Árpád híd' (2018) [8480.3].

Galium rubioides L. - Budapest XXIII, between M5 highway and 'Búzakéve utca', in tall sedge community (2017) [8581.3].

Geranium columbinum L. - Pest county, Pilisszentkereszt, Pilis Mts, near 'Dera-patak', on disturbed forest margins (2017) [8379.1]; Pest county, Budakalász, 'János utca', in garden, on disturbed ground (2017) [8380.3].

Geranium molle L. - Pest county, Budakalász, 'János utca', in garden, on disturbed ground (2017) [8380.3].

Geranium phaeum L. - Budapest III, 'Mocsáros', growing in one great patch alongside 'Schäfer-árok' (2017) [8480.1].

Geranium pyrenaicum Burm. f. - Pest county, Üröm, Buda Mts, 'Rókahegy', on disturbed ground at abandoned quarry (2017) [8480.1]; Budapest X, in 'Felsőrákosi rétek TT' protected area, alongside 'Rákos-patak' (2018) [8581.1].

Gladiolus imbricatus L. - Budapest XXIII, in the Soroksár Botanical Garden, in natural Molinia meadow (2018) [8580.4].

Glechoma hirsuta Waldst. \& Kit. - Pest county, Pomáz, Visegrád Mts, 'Kőhegy', frequent (2016) [8380.1].

Gleditsia triacanthos L. - Budapest IV, south of Megyeri bridge, in 'Újpest Homoktövis TT', at forest margin, subspontaneous (2018) [8380.4].

Glyceria fluitans (L.) R. Br. - Pest county, Pomáz, Visegrád Mts, 'Kő-hegy', 'Kö-hegyi-tó', in shallow water (2018) [8380.1].

Glyceria maxima (Hartm.) Holmb. - Pest county, Pomáz, Visegrád Mts, 'Kö-hegy', 'Kö-hegyi-tó', in shallow water and in the drying margin of the lake, on mud (2018) [8380.1].

Gnaphalium uliginosum L. - Pest county, Budakalász, in the bed of the Danube, opposite 'Lupa-sziget', in mud vegetation (2018) [8380.4]; Budapest IV, in the bed of the Danube near 'Palotai-sziget', in mud vegetation (2018) [8480.1]; 
Budapest V, on the rocky shore of the Danube near 'Széchenyi rakpart', on exposed mud between rocks (2018) [8480.3].

Gratiola officinalis L. - Budapest XXIII, in the Soroksár Botanical Garden, in natural Molinia meadow (2018) [8580.4].

Gypsophila paniculata L. - Budapest XIII, 'Árpád híd', some specimens in ruderal vegetation (2018) [8480.3]; Budapest XXIII, frequent in the territory of 'Soroksári Kísérleti Üzem és Tangazdaság', on sand (2018) [8680.2].

Helianthus tuberosus L. - Pest county, Cegléd, 'Fürdő út', alongside the road, at the forest margin (2018) [8884.1].

Helminthia echioides (L.) Gaertn. - Budapest III, 'Határ út', in dried concrete drainage canal, in fissures, not rare (2017) [8480.1]. In BP there are several sheets of the taxon from the same locality, the latest was collected by Somlyay in 2006 (BP, 687419).

Hesperis matronalis L. subsp. matronalis - Pest county, Pomáz, Visegrád Mts, 'Mesélö-hegy', at oak forest margin near gardens in 'Zuhatag utca', subspontaneous, 2 specimens (2017) [8380.1].

Hesperis tristis L. - Pest county, Üröm, Buda Mts, southern slope of 'Rókahegy', in rocky grassland (2018) [8480.1].

Hieracium baubini Schult ex Besser - Pest county, Budakalász, Pilis Mts, 'Monalovac', frequent in forests (2017) [8380.3].

Hieracium murorum L. - Pest county, Pomáz, Pilis Mts, Visegrád Mts, 'Köhegy', frequent in forests (2016) [8380.1]; Pest county, Budakalász, Pilis Mts, 'Monalovac', in black pine forest (2017) [8380.3]; Pest county, Üröm, Buda Mts, 'Róka-hegy', in grassland (2017) [8480.1].

Hieracium pilosella L. - Pest county, Budakalász, Pilis Mts, 'Monalovac', at the margin of planted black pine forests (2017) [8380.3].

Hieracium piloselloides Vill. - Pest county, Pomáz, Visegrád Mts, 'Kő-hegy', in dry degraded siliceous grassland near 'Petőfi-pihenő' (2016) [8380.1]. In BP there is only one sheet from 'Kö-hegy' and the whole Visegrád Mts from 1943, which is the type of Hieracium piloselloides Vill ssp. pseudoflorentiniforme Vajda \& Kováts (BP, 212480). There is only one sheet from the Pilis Mts under the name Hieracium Florentinum All. from 1903, 'in monte Pilis', collected by Jávorka (BP, 526605). According to BARTHA et al. (2015) the taxon is missing from the Dunazug Mts.

Holcus lanatus L. - Budapest III, 'Mocsáros', alongside channel 'Schäferárok' (2017) [8480.1].

Holosteum umbellatum L. - Budapest VIII, 'Könyves Kálmán körút', alongside road, in ruderal vegetation (2016) [8580.2]; Budapest XXIII, in the territory of 'Soroksári Kísérleti Üzem és Tangazdaság', on sand, as a weed (2016) [8680.2]. 
Hornungia petraea (L.) Rchb. - Pest county, Üröm, Buda Mts, southern slope of 'Róka-hegy', in rocky grassland (2017) [8480.1].

Hyacinthus orientalis L. - Pest county, Pilis, abundant in Robinia pseudoacacia plantation towards Albertirsa, subspontaneous (2018) [8783.1].

Hypericum tetrapterum Fr. - Pest county, Veresegyház, on the eastern shore of 'Pamut-tó', sporadic in tall-herb vegetation (2017) [8381.4].

Inula britannica L. - Pest county, Szentendre, Visegrád Mts, 'Izbég' and 'Kö-hegy', in grasslands and forest margins (2018) [8380.1]; Budapest III, on the rocky shore of the Danube near 'Árpád híd' (2018) [8480.3].

Inula salicina L. - Budapest III, 'Mocsáros', alongside channel 'Schäfer-árok' (2017) [8480.1].

Ipomoea purpurea (L.) Roth - Pest county, Vác, Cserhát Mts, north of 'Bükkös-hegy', some mature specimens growing in a dry grassland, at ruderal place near Rád (2017) [8281.1].

Isatis tinctoria L. - Budapest III, 'Békásmegyer' suburban railway station, between rails (2018) [8480.1].

Isopyrum thalictroides L. - Budapest II, Buda Mts, 'Látó-hegy', sporadic in deciduous forests (2016) [8480.3].

Jasione montana L. - Pest county, Pilisborosjenő, Pilis Mts, 'Ezüst-Kevély', in rocky slope near the top (2016) [8379.4].

Juncus bufonius L. - Pest county, Veresegyház, on the eastern shore of ' $\mathrm{Pa}$ mut-tó', at damp places alongside paths (2017) [8381.4].

Juncus compressus Jacq. - Pest county, Szentendre, on the stony shore of the Danube near 'Duna korzó' (2017) [8380.1]; Budapest III, 'Mocsáros', alongside channel 'Schäfer-árok' (2017) [8480.1].

Juncus inflexus L. - Komárom-Esztergom county, Pilisszentlélek (Esztergom), Pilis Mts, 'Kis-Szoplák', in mesotrophic deciduous forests, alongside paths (2017) [8279.3].

Juncus tenuis Willd. - Pest county, Veresegyház, on the eastern shore of 'Pamut-tó', at damp places alongside paths (2017) [8381.4].

Kochia laniflora (S. G. Gmel.) Borbás - Pest county, Veresegyház, on small sandy slope east of 'Pamut-tó' (2017) [8381.4].

Kochia prostrata (L.) Schrad. - Pest county, Érd, 'Érdi magaspart', on loess wall (2017) [8679.4]. The species has been recorded from "Sánc-hegy' (Érd) (KALAPOS \& SZERÉNYi 1997) and has records from three neighbouring grid cells (8679.1, 8679.2 and 8679.3).

Kochia scoparia (L.) Schrad. - Budapest X, 'Kőbányai út', sporadic alongside bikeway, in fissures (2018) [8580.2]. 
Koeleria cristata (L.) Pers. em. Borbás ex Domin - Budapest XXIII, in the territory of 'Soroksári Kísérleti Üzem és Tangazdaság', on long abandoned arable field, on sand (2018) [8680.2].

Lamium amplexicaule L. - Budapest XXIII, in the territory of 'Soroksári Kísérleti Üzem és Tangazdaság', on sand, as a weed (2016) [8680.2].

Lamium maculatum (L.) L. - Pest county, Budakalász, Pilis Mts, 'Nagy-Kevély', frequent in forests (2016) [8380.3].

Lappula squarrosa (Retz.) Dumort. - Budapest XIII, 'Árpád híd', few specimens in ruderal vegetation (2018) [8480.3].

Lathraea squamaria L. - Budapest II, Buda Mts, 'Kálvária-hegy', in oakhornbeam forest (2017) [8479.2].

Lathyrus sphaericus Retz. - Pest county, Budakalász, Pilis Mts, 'Monalovac', southwest of the quarry, on wasteland, frequent (2018) [8380.3].

Lavatera thuringiaca L. - Pest county, Göd, on the shore of 'Sződrákosipatak' and alongside roads (2017) [8280.4].

Lemna minor L. - Pest county, Szigetszentmiklós, 'Soroksári-Duna', in slowmoving water, at the margin of reeds (2017) [8680.2].

Lemna trisulca L. - Pest county, Dunaharaszti, in the drying reed of a pond near the railway bridge, on mud, frequent (2018) [8680.1].

Leontodon hispidus L. - Pest county, Veresegyház, on the eastern shore of 'Pamut-tó', at damp places (2017) [8381.4]; Budapest III, 'Mocsáros', alongside roads, in grasslands and on the wall of the amphitheatre (2017) [8480.1]; Budapest XI, in the Buda Arboretum, in mowed lawns, as a weed (2016) [8580.1].

Leonurus cardiaca L. - Komárom-Esztergom county, Dunaalmás, at the margins of the riparian forest (2017) [8275.4].

Leonurus marrubiastrum L. - Pest county, Pomáz, Visegrád Mts, 'Csikóvár', in oak forest, alongside wide forest road (2018) [8379.2]; Pest county, Pomáz, Visegrád Mts, 'Kö-hegy', 'Kő-hegyi-tó', in the drying margin of the lake, on mud (2018) [8380.1].

Leucanthemum vulgare Lam. - Pest county, Budakalász, Pilis Mts, 'EzüstKevély', in mesotrophic oak forest (2017) [8380.3]; Pest county, Budakalász, Pilis Mts, 'Monalovac', southwest of the quarry, on wasteland (2017) [8380.3].

Leucojum aestivum L. - Pest county, Budakalász, frequent in periodical marshes in the riparian forest (2017) [8380.4].

Ligustrum vulgare L. - Pest county, Pomáz, Visegrád Mts, 'Mesélő-hegy', frequent in forests (2017) [8380.1].

Limosella aquatica L. - Budapest IV, on the dried bed of a small branch of the Danube between 'Palotai-sziget' and 'Nép-sziget', in mud vegetation (2018) [8480.1]. 
Linaria genistifolia (L.) Mill. - Pest county, Budakalász, Pilis Mts, 'Monalovac', southwest of the quarry, on wasteland (2017) [8380.3]; Pest county, Veresegyház, east of 'Pamut-tó', few specimens on sand (2017) [8381.4]; Pest county, Üröm, Buda Mts, southern slope of 'Róka-hegy', in rocky grassland (2016) [8480.1].

Linaria vulgaris Mill. - Pest county, Dunaharaszti, frequent alongside roads near the Danube (2017) [8680.1].

Lindernia procumbens (Krock.) Philcox - Pest county, Göd, on the dried bed of a small creek of the Danube near 'Homoksziget', in mud vegetation, very few specimens (2018) [8380.2].

Linum catharticum L. - Pest county, Solymár, Buda Mts, 'Kálvária-hegy', sporadic in forest-grassland mosaic (2017) [8479.2].

Linum tenuifolium L. - Pest county, Budakalász, Pilis Mts, 'Monalovac', southwest of the quarry, in dry stony grassland (2017) [8380.3]; Pest county, Üröm, Buda Mts, southern slope of 'Róka-hegy', in rocky grassland (2016) [8480.1].

Lithospermum officinale L. - Pest county, Üröm, Buda Mts, 'Róka-hegy', southern slope of 'Róka-hegy', in rocky grassland (2017) [8480.1]; Budapest VIII, 'Könyves Kálmán körút', in the back yard of the Botanical Department of the Hungarian Natural History Museum (2018) [8580.2].

Lobularia maritima (L.) Desv. - Budapest XIII, 'Teve utca', one specimen in a fissure, subspontaneous (2018) [8480.3].

Lolium multiflorum Lam. - Pest county, Budakalász, 'János utca', in garden, on disturbed ground (2017) [8380.3]; Pest county, Érd, 'Molnár utca', in the territory of an abandoned brick factory, on disturbed ground (2017) [8679.2].

Lonicera tatarica L. - Pest county, Veresegyház, in damp forest alongside 'Sződrákosi-patak' south of 'Pamut-tó', few specimens, subspontaneous (2018) [8381.4].

Lotus tenuis Waldst. \& Kit. - Budapest III, 'Mocsáros', in Molinia meadow (2017) [8480.1]; Pest county, Dunaharaszti, on the shores of the ponds near the railway bridge (2017) [8680.1].

Lunaria annua L. - Pest county, Pilisborosjenő, Pilis Mts, 'Ezüst-Kevély', in oak forest, alongside paths close to gardens, subspontaneous (2016) [8379.4].

Luzula campestris (L.) DC. - Pest county, Budakalász, Pilis Mts, 'EzüstKevély', in acidofrequent oak forest (2016) [8380.3].

Lychnis coronaria (L.) Desr. - Pest county, Solymár, Buda Mts, between 'Kálvária-hegy' and 'Felső-patak-hegy', in secondary loessy grassland (2017) [8479.2].

Lychnis flos-cuculi L. - Pest county, Budakalász, Pilis Mts, 'Ezüst-Kevély', in oak forest (2017) [8380.3]. 
Lycopersicon esculentum Mill. - Pest county, Szentendre, in the bed of the Danube near 'Duna korzó', in mud vegetation, subspontaneous, frequent (2018) [8380.1].

Lythrum salicaria L. - Budapest XXIII, in the Soroksár Botanical Garden, in natural Molinia meadow (2018) [8580.4].

Macleaya cordata (Willd.) R.Br. - Budapest XI, on the corner of 'Bánát utca' and 'Nándorfejérvári út', some subspontaneously growing specimens near the parent plant (2018) [8580.1].

Mahonia aquifolium (Pursh) Nutt. - Budapest II, Buda Mts, 'Látó-hegy', frequent at forest margins (2016) [8480.3].

Malva neglecta Wallr. - Budapest VIII, 'Könyves Kálmán körút', alongside road, in ruderal vegetation (2017) [8580.2].

Matricaria recutita L. - Bács-Kiskun county, Tiszaug, east of the village, in saline grassland (2016) [9186.2].

Medicago $\times$ varia Martyn - Pest county, Budakalász, Pilis Mts, 'Monalovac', 'Kavicsos utca', near the quarry, alongside gravel road (2017) [8380.3].

Medicago minima (L.) L. - Pest county, Budakalász, Pilis Mts, 'Monalovac', southwest of the quarry, on wasteland (2017) [8380.3]; Pest county, Üröm, Buda Mts, southern slope of 'Róka-hegy', in rocky grassland (2017) [8480.1].

Medicago sativa L. - Budapest XI, in the Buda Arboretum, in mowed lawns, as a weed (2016) [8580.1].

Melica ciliata L. - Pest county, Pomáz, Visegrád Mts, 'Kö-hegy', in dry degraded siliceous grassland near 'Petőfi-pihenő' (2016) [8380.1].

Mentha aquatica L. - Komárom-Esztergom county, Esztergom, frequent on the shore on 'Dédai-tó' (2016) [8278.2].

Mentha longifolia (L.) Nath. - Budapest III, on the shore of the Danube near 'Árpád híd', in tall-herb vegetation (2018) [8480.3].

Mentha pulegium L. - Budapest V, on the rocky shore of the Danube near 'Szabadság híd', on exposed mud between rocks (2018) [8580.1].

Microrrbinum minus (L.) Fourr. - Budapest XI, 'Villányi út', in flower beds (2018) [8580.1].

Minuartia glaucina Dvořáková - Pest county, Üröm, Buda Mts, southern slope of 'Róka-hegy', in rocky grassland (2017) [8480.1].

Minuartia setacea (Thuill.) Hayek - Pest county, Pilisborosjenő, Pilis Mts, 'Nagy-Kevély', in open dolomite grassland (2016) [8379.4].

Mirabilis jalapa L. - Pest county, Vác, Cserhát Mts, north of 'Bükkös-hegy', in dry grassland, at ruderal place near Rád, subspontaneous (2017) [8281.1]; Budapest III, 'Mocsáros', in the amphitheatre, subspontaneous (2017) [8480.1].

Moehringia trinervia (L.) Clairv. - Pest county, Budakalász, Pilis Mts, 'Monalovac', in oak forest (2017) [8380.3]. 
Molinia caerulea (L.) Moench - Budapest III, 'Mocsáros', in Molinia meadow (2017) [8480.1].

Morus alba L. - Budapest III, on the rocky shore of the Danube near 'Árpád híd' (2018) [8480.3].

Muscari neglectum Guss. ex Ten. - Pest county, Üröm, Buda Mts, southern slope of 'Róka-hegy', in rocky grassland (2017) [8480.1].

Myosotis arvensis (L.) Hill - Pest county, Pomáz, Visegrád Mts, 'Kö-hegy', in grasslands near the plateau (2016) [8380.1].

Myosotis ramosissima Rochel - Pest county, Pomáz, Visegrád Mts, 'Kő-hegy', in forest-grassland mosaic (2016) [8380.1]; Pest county, Göd, in the area between the Budapest-Szob railway line and 'Összekötő út' (bikeway), in mesophilous sandy grassland (2018) [8380.2].

Myosoton aquaticum (L.) Moench - Komárom-Esztergom county, Pilisszentlélek (Esztergom), Pilis Mts, 'Kis-Szoplák', in tall herb vegetation (2017) [8279.3]; Budapest V, 'Erzsébet tér', in flower beds and in hedges (2018) [8580.1].

Narcissus pseudonarcissus L. - Pest county, Pilis, abundant in Robinia pseudoacacia plantation towards Albertirsa, subspontaneous (2018) [8783.1].

Nepeta $\times$ faasenii Bergmans ex Stearn - Budapest XIII, 'Margitsziget', at the ruins of the Dominican nunnery, sporadic on stone walls, subspontaneous (2018) [8480.3].

Nuphar lutea (L.) Sm. - Pest county, Dunaharaszti, in the water of 'SoroksáriDuna' (2017) [8680.2].

Nymphaea alba L. - Pest county, Dunaharaszti, in the water of 'SoroksáriDuna' (2017) [8680.2].

Odontites lutea (L.) Clairv. - Pest county, Üröm, Buda Mts, southern slope of 'Róka-hegy', in rocky grassland (2016) [8480.1].

Oenanthe aquatica (L.) Poir. - Pest county, Pomáz, Visegrád Mts, 'Kő-hegy', 'Kö-hegyi-tó', in the drying margin of the lake, on mud (2018) [8380.1].

Omphalodes scorpioides (Haenke) Schrank - Komárom-Esztergom county, Pilisszentlélek, Pilis Mts, 'Nagy-Bodzás-hegy', in rocky beech forest (2017) [8279.3].

Onopordum acanthium L. - Pest county, Göd, 'Kinizsi utca', alongside the $\operatorname{road}(2018)$ [8380.2].

Onosma arenaria Waldst. \& Kit. - Pest county, Üröm, Buda Mts, southern slope of 'Róka-hegy', in rocky grassland (2018) [8480.1].

Ophioglossum vulgatum L. - Budapest XXIII, in the Soroksár Botanical Garden, frequent in natural Molinia meadow (2018) [8580.4]. The data is known (BogyÁné \& KeCSKÉs 1993, KeCsKÉs \& KöBÖLKUTi 2016), but is missing from the atlas. 
Ornithogalum boucheanum (Kunth) Asch. - Budapest III, 'Vonat utca', on the shore of Aranyhegyi-patak (2018) [8480.1].

Ornithogalum kochii Parl. - Pest county, Budakalász, Pilis Mts, 'Monalovac', southwest of the quarry, in dry stony grassland (2017) [8380.3]; Bács-Kiskun county, Tiszaug, east of the village, in saline grassland (2016) [9186.2].

Ornithogalum refractum Kit. in Willd. - Budapest III, 'Ország út', at disturbed places (2016) [8480.1].

Orobanche alba Stephan ex Willd. - Nógrád county, Diósjenő, Börzsöny Mts, 'Dobó-bérc', in closed andesite grassland, parasitizing Origanum vulgare L. (2018) [8079.2].

Orobanche arenaria Borkh. - Budapest IV, in 'Újpesti Homoktövis TT', in sand steppe, parasitizing Artemisia campestris L. (2018) [8380.4].

Orobanche caryophyllacea Sm. - Pest county, Budakalász, Pilis Mts, 'EzüstKevély', on wide road, at the forest margin, parasitizing Galium sp. (2017) [8379.4].

Orobanche lutea Baumg. - Pest county, Budakalász, Pilis Mts, 'Monalovac', southwest of the quarry, in forest-grassland mosaic, parasitizing Medicago minima (L.) L. (2017) [8380.3].

Oxalis dillenii Jacq. - Budapest VIII, 'Könyves Kálmán körút', alongside road, in ruderal vegetation (2016) [8580.2].

Padus serotina (Ehrh.) Borkh. - Pest county, Veresegyház, on the eastern shore of 'Pamut-tó', subspontaneous (2018) [8381.4].

Panicum capillare L. - Pest county, Budakalász, in the bed of the Danube, opposite 'Lupa-sziget', in mud vegetation (2018) [8380.3].

Panicum miliaceum L. - Pest county, Solymár, north of 'Aranyhegyi-patak', alongside gravel roads next to arable fields (2017) [8479.2].

Papaver dubium L. subsp. albiflorum (Boiss.) Dostál - Pest county, Budakalász, 'János utca', in garden, on disturbed ground (2017) [8380.3].

Parietaria officinalis L. - Budapest XI, Buda Mts, 'Rupp-hegy', frequent alongside forest roads (2016) [8579.2].

Parthenocissus inserta (A. Kern.) Fritsch - Pest county, Budakalász, 'Duna sétány', climbing on trees (2018) [8380.4].

Paulownia tomentosa (Thunb.) Steud. - Budapest I, 'Alkotás utca', at 'Déli' railway terminal, in fissure, one specimen (2018) [8580.1].

Persicaria amphibia (L.) Delarbre - Budapest X, in 'Felsőrákosi rétek TT' protected area, south of 'Rákos-patak', in the dried border of a small lake, on exposed mud [8581.1].

Persicaria dubia (Stein) Fourr. - Pest county, Pilisszentkereszt, Pilis Mts, 'Kakas-hegy', alongside wide forest road (2016) [8279.3]; Pest county, Buda- 
kalász, in the bed of the Danube, opposite 'Lupa-sziget', in mud vegetation (2018) [8380.4].

Persicaria lapathifolia (L.) Delarbre - Pest county, Veresegyház, on the sandy shore of 'Álom-hegyi víztározó' (2017) [8381.4].

Persicaria minor (Huds.) Opiz - Komárom-Esztergom county, Pilisszentlélek (Esztergom), Pilis Mts, 'Kis-Szoplák', in tall herb vegetation (2017) [8279.3]; Pest county, Pomáz, Visegrád Mts, 'Csikóvár', 'Tó-lak', on the drying bed of the eastern swamp ('Csikóvári-tó') (2018) [8379.2]; Pest county, Pomáz, Visegrád Mts, 'Kö-hegy', 'Kö-hegyi-tó', in the drying margin of the lake, on mud (2018) [8380.1].

Petunia $\times$ atkinsiana D. Don - Budapest XIII, 'Gömb utca', some specimens in ruderal vegetation, subspontaneous (2018) [8480.3]; Tolna county, Dunaföldvár, 'Sóház utca', two specimens growing on a wall, subspontaneous (2018) [9179.4].

Peucedanum alsaticum L. - Pest county, Budakalász, Pilis Mts, 'Monalovac', southwest of the quarry, on wasteland (2018) [8380.3].

Peucedanum cervaria (L.) Lapeyr. - Pest county, Budakalász, Pilis Mts, 'Monalovac', southwest of the quarry, in dry stony grassland (2018) [8380.3].

Phalaris arundinacea L. - Pest county, Pomáz, Visegrád Mts, 'Kő-hegy', 'Kőhegyi-tó', in shallow water (2018) [8380.1].

Physalis peruviana L. - Budapest I, on the rocky shore of the Danube near 'Batthyány tér', about 15 flowering and several vegetative specimens in November, subspontaneous (2018) [8480.3]; Budapest IX, on the rocky shore of the Danube near 'Petőfi híd', 1 flowering and several vegetative specimens in November, subspontaneous (2018) [8580.1]. The only observed occurences in Hungary were in the 'Szigetköz', in the city of Györ and Zala county (SCнмidT 2013).

Phytolacca americana L. - Pest county, Budakalász, at the Danube floodplain, at the margin of riparian forest (2018) [8380.4].

Phytolacca esculenta van Houtte - Pest county, Budakalász, behind the football pitch, at rubbishy place, on disturbed ground (2017) [8380.3].

Plantago altissima L. - Budapest III, sporadic on the rocky shore of the Danube near 'Árpád híd' (2018) [8480.3]; Budapest IX, sporadic on the rocky shore of the Danube near 'Fővám tér' (2018) [8580.1].

Plantago indica L. - Pest county, Göd, in the area between the BudapestSzob railway line and 'Összekötő út' (bikeway), in sand steppe (2017) [8380.2]; Budapest XIII, 'Árpád híd', some specimens in ruderal vegetation (2018) [8480.3].

Plantago tenuiflora Waldst. \& Kit. - Bács-Kiskun county, Tiszaug, east of the village, in saline grassland (2016) [9186.2]. 
Platanus $\times$ bybrida Brot. - Budapest III, some young specimens on the rocky shore of the Danube near 'Árpád híd', subspontaneous (2018) [8480.3].

Poa angustifolia L. - Pest county, Budakalász, 'Sport utca', near the football pitch, in uncharacteristic grassland (2016) [8380.3]; Pest county, Solymár, Buda Mts, 'Kálvária-hegy', in forest-grassland mosaic (2018) [8479.2].

Poa annua L. - Budapest I, frequent in flower beds and on disturbed grounds (2017) [8480.3].

Poa palustris L. - Budapest III, 'Vonat utca', on the shore of 'Aranyhegyipatak' (2018) [8480.1]; Budapest III, on the rocky shore of the Danube near 'Árpád híd' (2018) [8480.3]; Budapest IX, on the rocky shore of the Danube near 'Fővám tér', on exposed mud between rocks (2018) [8580.1].

Podospermum canum (C. A. Mey.) Griseb. - Pest county, Budakalász, 'OMSZK park', near road 11, on disturbed ground (2017) [8380.3]; Budapest XI, 'Somló köz', one specimen on bare soil (2018) [8580.1].

Polygonum arenastrum Boreau - Pest county, Veresegyház, near 'Álom-hegyi víztározó', in disturbed sandy grasslands (2017) [8381.4].

Polygonum bellardii All. - Pest county, Veresegyház, on small sandy slope east of 'Pamut-tó' (2017) [8381.4].

Polypodium vulgare L. - Pest county, Pilisborosjenő, Pilis Mts, 'Köves-bérc', in acidofrequent oak forest, between rocks (2017) [8379.4].

Populus tremula L. - Pest county, Pomáz, Visegrád Mts, 'Csikóvár', 'Tó-lak', in mixed oak forest (2018) [8379.2].

Portulaca grandiflora Hook. - Budapest IV, in the bed of the Danube near 'Palotai-sziget', in mud vegetation, one specimen, subspontaneous (2018) [8480.1].

Potamogeton lucens L. - Győr-Moson-Sopron county, Mosonmagyaróvár, in the water of 'Mosoni-Duna' (2018) [8169.2].

Potamogeton nodosus Poir. - Győr-Moson-Sopron county, Mosonmagyaróvár, in the water of 'Mosoni-Duna' (2018) [8170.3].

Potamogeton perfoliatus L. - Győr-Moson-Sopron county, Mosonmagyaróvár, in the water of 'Mosoni-Duna' (2018) [8069.4].

Potentilla arenaria Borkh. - Pest county, Pomáz, Visegrád Mts, 'Kö-hegy', frequent (2016) [8380.1]; Pest county, Üröm, Buda Mts, southern slope of 'Rókahegy', in rocky grassland (2017) [8480.1].

Potentilla argentea L. - Pest county, Pomáz, Visegrád Mts, 'Kö-hegy', frequent (2016) [8380.1].

Potentilla supina L. - Pest county, Dunabogdány, in the bed of the Danube, in mud vegetation (2018) [8180.3]; Budapest IV, on the dried bed of a small branch of the Danube between 'Palotai-sziget' and 'Nép-sziget', in mud vegetation (2018) [8480.1]. 
Primula veris L. - Budapest II, Buda Mts, 'Látó-hegy', frequent in mixed oak forests (2016) [8480.3].

Prunella grandiflora (L.) Scholler - Budapest II, Buda Mts, 'Kálvária-hegy', sporadic in forest-grassland mosaic (2016) [8479.2].

Prunella laciniata L. - Pest county, Budakalász, few specimens in a natural grassland patch under 'Holló utca' (2017) [8380.3].

Prunella vulgaris L. - Budapest III, 'Mocsáros', frequent in mesic grasslands (2017) [8480.1].

Pseudolysimachion spicatum (L.) Opiz - Pest county, Pomáz, Visegrád Mts, 'Mesélö-hegy', in forest-grassland mosaic (2016) [8380.1]; Pest county, Üröm, Buda Mts, southern slope of 'Róka-hegy', in rocky grassland (2016) [8480.1].

Puccinellia distans (Jacq.) Parl. - Pest county, Dunabogdány, in the bed of the Danube, in mud vegetation (2018) [8180.3]; Budapest IV, 'Váci út', in fissures (2018) [8380.4]; Budapest I, 'Sztehlo Gábor rakpart', in fissures (2018) [8480.3].

Pulicaria dysenterica (L.) Bernh. - Budapest III, 'Mocsáros', alongside channel 'Schäfer-árok' (2017) [8480.1]; Pest county, Dunaharaszti, in reeds alongside 'Soroksári-Duna' and on the shore of the ponds near the railway bridge (2017) [8680.1]; Pest county, Cegléd, near 'Ceglédi Termálfürdő', on the shore of a small pond (2018) [8884.1].

Pulmonaria officinalis L. - Pest county, Pomáz, Visegrád Mts, 'Kő-hegy', frequent in forests (2016) [8380.1].

Pulsatilla grandis Wender. - Pest county, Pilisborosjenő, 'Nagy-Kevély', in open dolomite grassland (2017) [8379.4].

Quercus rubra L. - Budapest IV, in 'Újpesti Homoktövis TT', on sand, subspontaneous (2018) [8380.4].

Ranunculus acris L. - Budapest III, next to 'Árpád híd', in mowed lawn (2018) [8480.3].

Ranunculus ficaria L. subsp. bulbilifera Lamb. - Pest county, Budakalász, alongside roads and streams and in forests (2016) [8380.3]; Pest county, Pomáz, alongside roads and streams and in forests (2017) [8380.1].

Ranunculus pedatus Waldst. \& Kit. - Bács-Kiskun county, Tiszaug, east of the village, in saline grassland (2016) [9186.2].

Ranunculus polyanthemos L. - Pest county, Budakalász, frequent in grasslands in and near the town (2016) [8380.3].

Ranunculus polyphyllus Waldst. \& Kit. - Pest county, Pomáz, Visegrád Mts, 'Csikóvár', 'Tó-lak', in the western swamp, in shallow water (2018) [8379.2]; Pest county, Pomáz, Visegrád Mts, 'Kő-hegy', 'Kö-hegyi-tó', on the drying margin of the lake, on mud (2018) [8380.1]. The atlas states that the last known data from grid cell 8380.1 was recorded before 1950, and suggests that the species does not occur in grid cell 8379.2. In BP there are several sheets for the species from these 
two grid cells, the latest sheet from 8379.2 was collected by Pénzes in 'Csikóváritó' in 1958 (BP, 380709) and the latest from 8380.3 was collected by Bánó in 'Köhegy' in 1953 (BP, 197354).

Raphanus raphanistrum L. - Pest county, Veresegyház, in disturbed sandy grasslands (2018) [8381.4]; Budapest VIII, 'Könyves Kálmán körút', alongside road, in ruderal vegetation (2017) [8580.2].

Raphanus sativus L. - Budapest IX, 'Könyves Kálmán körút', alongside abandoned tramway track near 'Lenkei János utca', one specimen in a fissure, subspontaneous (2018) [8580.2].

Rhus typhina L. - Budapest III, 'Táncsics Mihály utca', young specimens under older tree, subspontaneous (2018) [8380.3].

Ribes rubrum L. - Pest county, Pilisborosjenő, Pilis Mts, 'Ezüst-Kevély', in mesophilous mixed oak forest near the quarry, subspontaneous (2017) [8380.3].

Robinia viscosa Vent. - Pest county, Budakalász, Pilis Mts, 'Monalovac', southwest of the quarry, in scrubland, subspontaneous (2017) [8380.3].

Rorippa $\times$ anceps (Wahlenb.) Rchb. - Pest county, Dunabogdány, in the bed of the Danube, in mud vegetation (2018) [8180.3]; Pest county, Dunabogdány, on the shore of the Danube (2017) [8280.1].

Rorippa amphibia (L.) Besser - Pest county, Pomáz, Visegrád Mts, 'Csikóvár', 'Tó-lak', in the western swamp, in shallow water (2018) [8379.2]; Pest county, Pomáz, Visegrád Mts, 'Kö-hegy', 'Kö-hegyi-tó', in shallow water and on the drying margin of the lake (2018) [8380.1]; Tolna county, Bölcske; on the shore of the Danube, on mud (2018) [9279.4].

Rorippa austriaca (Crantz) Besser - Pest county, Budakalász, sporadic in grasslands in and near the town (2017) [8380.3].

Rorippa palustris (L.) Besser - Pest county, Budakalász, in the bed of the Danube, opposite 'Lupa-sziget', in mud vegetation (2018) [8380.4].

Rorippa sylvestris (L.) Besser - Pest county, Dunabogdány, on the shore of the Danube (2017) [8280.1]; Pest county, Budakalász, in the bed of the Danube, opposite 'Lupa-sziget', in mud vegetation (2018) [8380.4].

Rumex conglomeratus Murray - Pest county, Budakalász, in riparian forest (2017) [8380.4]; Budapest III, 'Mocsáros', alongside channel 'Schäfer-árok' (2017) [8480.1]; Budapest III, on the rocky shore of the Danube near 'Árpád híd' (2018) [8480.3].

Rumex obtusifolius L. - Pest county, Piliscsaba, near 'Piliscsaba' railway station, in ruderal vegetation (2018) [8378.4].

Rumex palustris Sm. - Pest county, Göd, in the area between 'Sződrákosipatak', 'Ilka-patak' and 'István utca', in Salix caprea scrub (2017) [8280.4].

Rumex patientia L. - Pest county, Budakalász, Pilis Mts, 'Monalovac', southwest of the quarry, alongside roads in a scrubland (2017) [8380.3]. 
Rumex sanguineus L. - Pest county, Csobánka, Pilis Mts, 'Kis-Kevély', in forests (2017) [8379.4].

Rumex stenophyllus Ledeb. - Budapest III, 'Mocsáros', sporadic in wet meadow (2017) [8480.1].

Ruta graveolens L. - Budapest XXIII, in the territory of 'Soroksári Kísérleti Üzem és Tangazdaság', alongside roads, on sand, subspontaneous (2016) [8680.2].

Sagina procumbens L. - Budapest III, 'Csillaghegy', frequent in fissures (2018) [8480.1].

Salix caprea L. - Pest county, Göd, in the area between 'Sződrákosi-patak', 'Ilka-patak', and 'István utca', a decent population in a Molinia meadow (2017) [8280.4].

Salvia pratensis L. - Pest county, Pomáz, Visegrád Mts, 'Mesélő-hegy', in forest-grassland mosaic (2017) [8380.1].

Salvinia molesta D. S. Mitch. - Komárom-Esztergom county, Dunaalmás, in hot sulphurous spring near the Danube, covers almost the whole water surface, subspontaneous (2017) [8275.4]. The species has two records from Hungary, both from Budapest ('Lukács-fürdő' and 'Margit-sziget') from grid cell 8480.3 (KoRDA et al. 2008). Mesterházy found the species in the same location in 2015, but has never published the data (Mesterházy ex verb.).

Saponaria officinalis L. - Györ-Moson-Sopron county, Rajka, on the shore of 'Mosoni-Duna', in a camping (2016) [8069.1].

Saxifraga bulbifera L. - Pest county, Budakalász, Pilis Mts, 'Monalovac', in young shrubland (2017) [8380.3].

Saxifraga tridactylites L. - Pest county, Üröm, Buda Mts, 'Róka-hegy', on bare soil (2017) [8480.1].

Scabiosa ochroleuca L. - Pest county, Üröm, Buda Mts, southern slope of 'Róka-hegy', in rocky grassland (2016) [8480.1].

Schoenoplectus lacustris (L.) Palla - Pest county, Pomáz, Visegrád Mts, 'Köhegy', 'Kö-hegyi-tó', in the drying margin of the lake, on mud (2018) [8380.1]; Budapest III, 'Mocsáros', in wet meadow (2017) [8480.1].

Scirpus sylvaticus L. - Pest county, Veresegyház, in damp forest alongside 'Sződrákosi-patak' south of 'Pamut-tó' (2018) [8381.4].

Scorzonera austriaca L. - Pest county, Üröm, Buda Mts, southern slope of 'Róka-hegy', in rocky grassland (2017) [8480.1].

Secale cereale L. - Pest county, Fót, 'Fáy-sétány', on disturbed sandy ground, subspontaneous (2018) [8381.3].

Sedum acre L. - Pest county, Pomáz, Visegrád Mts, 'Kő-hegy', in dry degraded siliceous grassland near 'Petőfi-pihenő' (2016) [8380.1].

Sempervivum marmoreum Griseb. - Pest county, Nagykovácsi, Buda Mts, 'Remete-hegy', above 'Remetei kőfülke', in limestone grassland (2017) [8479.2]. 
Senecio erucifolius L. - Pest county, Göd, in the area between 'Sződrákosipatak', 'Ilka-patak', and 'István utca', in Molinia meadow (2017) [8280.4].

Senecio vernalis Waldst. \& Kit. - Budapest II, Buda Mts, 'Kálvária-hegy', frequent alongside roads and paths (2016) [8479.2]; Budapest XIII, 'Róbert Károly körút', in ruderal vegetation (2018) [8480.3].

Senecio vulgaris L. - Pest county, Budakalász, 'János utca', in garden, on disturbed ground (2017) [8380.3].

Seseli annuum L. - Pest county, Budakalász, Pilis Mts, 'Monalovac', southwest of the quarry, in dry stony grassland (2018) [8380.3].

Setaria verticillata (L.) P. Beauv. - Budapest III, 'Békásmegyer', frequent alongside roads (2018) [8480.1].

Silene otites (L.) Wibel - Pest county, Üröm, Buda Mts, 'Róka-hegy', in dry grasslands (2017) [8480.1].

Silybum marianum (L.) Gaertn. - Budapest III, at 'Szentlélek tér' suburban railway station, at the end of platform 'A', about 15 specimens growing in ruderal vegetation (2018) [8480.3].

Sinapis arvensis L. - Budapest XXIII, 'Telefondülö út', in the territory of 'Soroksári Kísérleti Üzem és Tangazdaság', on sandy arable fields, as a weed (2018) [8680.2].

Sisymbrium loeselii L. - Budapest III, 'Zsófia utca', alongside the road (2017) [8480.1].

Smyrnium perfoliatum L. - Komárom-Esztergom county, Pilisszentlélek, Pilis Mts, 'Nagy-Szoplák', in beech forest (2017) [8279.3].

Solanum nigrum L. subsp. schultesii (Opiz) Wessely - Pest county, Budakalász, 'Posta köz', on disturbed ground, few specimens (2018) [8380.3].

Solidago gigantea Aiton - Pest county, Solymár, alongside road 10 east of the settlement (2017) [8479.2].

Sonchus arvensis L. subsp. uliginosus (M. Bieb.) Nyman - Pest county, Cegléd, near 'Ceglédi Termálfürdo', on the shore of a small pond (2018) [8884.1].

Sonchus asper (L.) Hill - Fejér county, Vértesacsa, on farm, as a weed (2018) [8677.2].

Sonchus oleraceus L. - Pest county, Budakalász, on disturbed grounds (2017) [8380.3].

Sorghum halepense (L.) Pers. - Budapest III, 'Szentlélek tér', at the bus stop, in ruderal vegetation (2018) [8480.3]; Pest county, Budaörs, 'Budakeszi utca', at construction site (2017) [8579.2].

Sparganium erectum L. - Pest county, Pomáz, Visegrád Mts, 'Kő-hegy', 'Kőhegyi-tó', in the drying margin of the lake, on mud (2018) [8380.1]; Budapest III, 'Mocsáros', in channel 'Schäfer-árok', in slow-moving water (2017) [8480.1]. 
Spirodela polyrrhiza (L.) Schleid. - Pest county, Szigetszentmiklós, 'Soroksári-Duna', in slow-moving water, at the margin of reeds (2017) [8680.2].

Stachys annua L. - Budapest XIII, 'Visegrádi utca', in ruderal vegetation (2018) [8480.3].

Stachys germanica L. - Pest county, Szentendre, Visegrád Mts, 'Izbég', in loess grasslands (2018) [8380.1].

Stachys palustris L. - Budapest III, on the rocky shore of the Danube near 'Árpád híd' (2018) [8480.3].

Staphylea pinnata L. - Pest county, Csobánka, Pilis Mts, 'Kis-Kevély', in mesophilous deciduous forests (2018) [8379.4].

Stellaria graminea L. - Pest county, Pomáz, Visegrád Mts, 'Kö-hegy', on the plateau, in disturbed grasslands (2017) [8380.1]; Pest county, Budakalász, Pilis Mts, 'Monalovac', in forest clearings and disturbed grasslands (2017) [8380.3].

Stellaria holostea L. - Pest county, Pomáz, Pilis Mts, Mesélő-hegy (Messelia), in mesotrophic forests (2017) [8380.1].

Stellaria media (L.) Vill. - Pest county, Pomáz, in nitrophilous places (2017) [8380.1].

Stipa capillata L. - Pest county, Üröm, Buda Mts, southern slope of 'Rókahegy', in rocky grassland (2016) [8480.1].

Stipa eriocaulis Borbás - Budapest II, Buda Mts, 'Kálvária-hegy', in open dolomite grassland (2017) [8479.2].

Stipa pennata L. - Pest county, Göd, in the area between the Budapest-Szob railway line and 'Összekötő út' (bikeway), in sand steppe (2018) [8380.2].

Succisa pratensis Moench - Budapest III, 'Mocsáros', sporadic in wet meadows (2018) [8480.1] In BP there are several sheets of the taxon from the same locality, the latest was collected by Somlyay in 2006 (BP, 687193).

Symphytum tuberosum L. - Pest county, Pomáz, Visegrád Mts, 'Kö-hegy' and 'Mesélö-hegy', frequent in forests (2016) [8380.1].

Syringa vulgaris L. - Pest county, Budakalász, Pilis Mts, 'Monalovac', southwest of the quarry, in shrubland, a great population, subspontaneous (2018) [8380.3].

Tanacetum parthenium (L.) Sch. Bip. - Budapest II, Buda Mts, 'Kálváriahegy', 'Emelkedö utca', some specimens alongside the road, subspontaneous (2018) [8479.2].

Taxus baccata L. - Budapest XII, Buda Mts, 'Hunyad-orom', some young specimens in stony mixed oak forest, subspontaneous (2018) [8479.4]; Budapest II, Buda Mts, 'Kecske-hegy', alongside 'Szépvölgyi út', some young specimens in fissures, subspontaneous (2018) [8480.3]. 
Telekia speciosa (Schreb.) Baumg. - Nógrád county, Diósjenő, Börzsöny Mts, near 'Diósjenői Erdei Szabadidőpark', at forest margin, one specimen (2018) [8080.3]. Probably planted, not mentioned by NAGY (2007).

Tetragonolobus maritimus (L.) Roth. subsp. siliquosus (L.) Murb. - Budapest III, 'Mocsáros', frequent in mesic grasslands and meadows (2017) [8480.1].

Thalictrum flavum L. - Budapest XXIII, in the Soroksár Botanical Garden, sporadic in natural Molinia meadow (2018) [8580.4].

Thesium ramosum Hayne - Pest county, Pomáz, Pilis Mts, 'Mesélő-hegy', in grasslands (2017) [8380.1]; Pest county, Üröm, Buda Mts, southern slope of 'Róka-hegy', in rocky grassland (2017) [8480.1].

Thlaspi arvense L. - Pest county, Szentendre, Visegrád Mts, 'Izbég', at construction site (2018) [8380.1]; Budapest XXIII, 'Telefondülő út', in the territory of 'Soroksári Kísérleti Üzem és Tangazdaság', on sandy arable fields, as a weed (2018) [8680.2].

Thlaspi perfoliatum L. - Pest county, Göd, frequent alongside roads (2018) [8380.2].

Thrincia nudicaulis (L.) Dostál - Pest county, Dunabogdány, in the bed of the Danube, in mud vegetation (2018) [8180.3].

Thuja occidentalis L. - Budapest XII, Buda Mts, 'Tündér-hegy', some young specimens in stony mixed oak forest, subspontaneous (2018) [8479.4].

Thuja orientalis L. - Budapest II, Buda Mts, 'Kálvária-hegy', in open dolomite grassland, some young specimens, subspontaneous (2017) [8479.2].

Thymus pannonicus All. - Pest county, Pomáz, Visegrád Mts, 'Mesélő-hegy', in forest-grassland mosaic (2017) [8380.1].

Thymus praecox Opiz - Pest county, Üröm, Buda Mts, southern slope of 'Róka-hegy', in rocky grassland (2017) [8480.1].

Tilia cordata Mill. - Pest county, Pomáz, Visegrád Mts, 'Mesélő-hegy', in mixed oak forest (2017) [8380.1].

Tordylium maximum L. - Budapest III, 'Ország út', alongside the road (2016) [8480.1].

Torilis arvensis (Huds.) Link - Pest county, Pilisvörösvár, Pilis Mts, 'Zajnáthegyek', in planted black pine forest, alongside paths (2018) [8379.3]; Budapest III and Üröm, frequent is grasslands and ruderal places (2017) [8480.1].

Tragus racemosus (L.) All. - Pest county, Veresegyház, on small sandy slope east of 'Pamut-tó' (2017) [8381.4].

Tribulus terrestris L. subsp. terrestris - Budapest III, on the corner of 'Tavasz utca' and 'Hídfo' utca', in ruderal vegetation (2018) [8480.3]; Budapest VIII, on the corner of 'Könyves Kálmán körút' and 'Vajda Péter utca', in ruderal vegetation (2017) [8580.2]. 
Trifolium aureum Pollich - Pest county, Pilisszántó, Pilis Mts, above 'Deraszurdok', in degraded, disturbed places alongside forest roads (2017) [8379.1].

Trifolium campestre Schreb. - Pest county, Pilisborosjenő, Pilis Mts, 'EzüstKevély', in clearings of oak forests (2016) [8380.3].

Trifolium fragiferum L. - Pest county, Dunaharaszti, on the shore of the ponds near the railway bridge (2017) [8680.1].

Trifolium hybridum L. - Pest county, Veresegyház, in disturbed sandy grasslands (2017) [8381.4].

Trifolium incarnatum L. - Budapest XXIII, 'Telefondűlö út', in the territory of 'Soroksári Kísérleti Üzem és Tangazdaság', on sandy arable fields, as a weed, subspontaneous (2018) [8680.2].

Trifolium pratense L. - Pest county, Veresegyház, on the eastern shore of 'Pamut-tó', at damp places (2017) [8381.4].

Trinia glauca (L.) Dumort. - Pest county, Szentendre, Visegrád Mts, 'Izbég', in loessy grassland (2018) [8380.1]; Pest county, Üröm, Buda Mts, southern slope of 'Róka-hegy', in rocky grassland (2017) [8480.1].

Tripleurospermum perfoliatum (Mérat) M. Laínz - Komárom-Esztergom county, Esztergom, Visegrád Mts, south of 'Csenke-patak', alongside roads (2016) [8278.2]; Pest county, Pilisborosjenő, Pilis Mts, north-west of 'Köves-bérc', in corn and sunflower fields (2016) [8379.4].

Typha laxmannii Lepech. - Pest county, Cegléd, near 'Ceglédi Termálfürdő', on the shore of a small pond (2018) [8884.1].

Ulmus minor Mill. - Budapest IV, near M0 highway, in forests and at forest margins (2018) [8380.4].

Urtica urens L. - Budapest V, 'Balaton utca', some specimens in a front gar$\operatorname{den}(2018)$ [8480.3].

Valerianella carinata Loisel. - Pest county, Budakalász, 'OMSZK park', near road 11, on disturbed ground (2017) [8380.3].

Valerianella locusta (L.) Laterr. - Budapest XXIII, in the territory of 'Soroksári Kísérleti Üzem és Tangazdaság', on long abandoned arable field, on sand (2018) [8680.2].

Verbascum blattaria L. - Pest county, Göd, in the area between the Budapest-Szob railway line and 'Összekötő út' (bikeway), in mesophilous sandy grassland (2017) [8380.2]; Budapest XXIII, in the territory of 'Soroksári Kísérleti Üzem és Tangazdaság', on long abandoned arable field, on sand (2018) [8680.2].

Verbascum chaixii Vill. subsp. austriacum (Schott) Hayek - Budapest II, Buda Mts, 'Kálvária-hegy', on wastelands (2017) [8479.2]. 
Verbascum lychnitis L. - Pest county, Csobánka, Pilis Mts, 'Kis-Kevély', in oak forest clearings (2017) [8379.4].

Verbascum nigrum L. - Pest county, Dunaharaszti, alongside the gravel road between the two ponds near the railway bridge (2017) [8680.1].

Veronica anagallis-aquatica L. - Pest county, Szentendre, in the bed of the Danube near 'Duna korzó', in mud vegetation (2018) [8380.1]; Pest county, Göd, in the bed of the Danube near the ferry station, in mud vegetation (2018) [8380.2]; Pest county, Veresegyház, on the sandy shore of 'Álom-hegyi víztározó' (2017) [8381.4].

Veronica catenata Pennell - Pest county, Dunabogdány, in the bed of the Danube, in mud vegetation (2018) [8180.3]; Pest county, Budakalász, in the bed of the Danube, opposite 'Lupa-sziget', in mud vegetation (2018) [8380.4]; Budapest X, in 'Felsőrákosi rétek TT' protected area, south of 'Rákos-patak', in the dried border of a small lake, on exposed mud (2018) [8581.1].

Veronica chamaedrys L. - Pest county, Pomáz, Visegrád Mts, 'Mesélő-hegy', in forest-grassland mosaic (2017) [8380.1].

Veronica hederifolia L. s. 1. - Pest county, Pomáz, frequent (2016) [8380.1]; Pest county, Budakalász, frequent [8380.3]; Jász-Nagykun-Szolnok county, Tiszakürt, frequent (2016) [9186.2].

Veronica peregrina L. - Pest county, Dunabogdány, in the bed of the Danube, in mud vegetation (2018) [8180.3].

Veronica persica Poir. - Pest county, Budakalász, frequent (2016) [8380.3].

Veronica prostrata L. - Pest county, Göd, in the area between the BudapestSzob railway line and 'Összekötő út' (bikeway), in mesophilous sandy grassland (2018) [8380.2]; Bács-Kiskun county, Tiszaug, east of the village, in saline grassland (2016) [9186.2].

Veronica serpyllifolia L. - Pest county, Pomáz, Visegrád Mts, 'Csikóvár', 'Tólak', in open oak forest (2018) [8379.2].

Veronica teucrium L. - Pest county, Göd, in the area between 'Sződrákosipatak', 'Ilka-patak', and 'István utca' at the margin of a Molinia meadow (2017) [8280.4]; Pest county, Üröm, Pilis Mts, 'Ezüst-Kevély', in forests and at forest margins (2016) [8380.3].

Veronica triphyllos L. - Budapest XXIII, in the territory of 'Soroksári Kísérleti Üzem és Tangazdaság', on sand, as a weed (2016) [8680.2].

Viburnum lantana L. - Budapest IV, north of Megyeri bridge, along the bank (2018) [8380.4].

Vicia angustifolia L. - Pest county, Budakalász, frequent in secondary grasslands (2016) [8380.3]; Budapest XI, 'Dombóvári út', in hedges (2016) [8580.1]; 
Budapest XXIII, in the territory of 'Soroksári Kísérleti Üzem és Tangazdaság', on sand, as a weed (2018) [8580.4].

Vicia cracca L. - Pest county, Szentendre, in secondary grasslands (2016) [8380.4].

Vicia dumetorum L. - Komárom-Esztergom county, Pilisszentlélek (Esztergom), Pilis Mts, 'Pilis-hegy', sporadic in mesotrophic deciduous forests (2017) [8379.1].

Vicia grandiflora Scop. - Jász-Nagykun-Szolnok county, Tiszakürt, on the Tisza floodplain, on the embankment (2016) [9186.2].

Vicia hirsuta (L.) Gray - Pest county, Szentendre, Visegrád Mts, 'Izbég', in loessy grassland (2018) [8380.1]; Budapest XXIII, in the territory of 'Soroksári Kísérleti Üzem és Tangazdaság', on sand, as a weed (2018) [8580.4].

Vicia lathyroides L. - Budapest XXIII, in the territory of 'Soroksári Kísérleti Üzem és Tangazdaság', on long abandoned arable field, on sand (2018) [8680.2]; Bács-Kiskun county, Tiszaug, east of the village, in saline grassland (2016) [9186.2].

Vicia pannonica Crantz subsp. pannonica - Pest county, Budakalász, Pilis Mts, 'Monalovac', southwest of the quarry, on wasteland (2018) [8380.3].

Vicia pannonica Crantz subsp. striata (M. Bieb.) Nyman - Pest county, Budakalász, Pilis Mts, 'Monalovac', southwest of the quarry, in sparsely planted black pine forest (2018) [8380.3].

Vicia tenuifolia Roth - Pest county, Budakalász, Pilis Mts, 'Monalovac', southwest of the quarry, on wasteland (2017) [8380.3].

Vicia villosa Roth - Budapest XIII, 'Róbert Károly körút', in ruderal vegetation (2018) [8480.3].

Vinca herbacea Waldst. \& Kit. - Pest county, Üröm, Buda Mts, southern slope of 'Róka-hegy', in rocky grassland (2017) [8480.1].

Vincetoxicum hirundinaria Medik. - Pest county, Pomáz, Pilis Mts, Visegrád Mts, 'Kö-hegy', in forests (2016) [8380.1].

Viola ambigua Waldst. \& Kit. - Pest county, Üröm, Buda Mts, southern slope of 'Róka-hegy', in rocky grassland (2017) [8480.1].

Viola canina L. - Pest county, Pomáz, Visegrád Mts, 'Csikóvár', 'Tó-lak', near the western swamp, in damp open oak forest (2018) [8379.2].

Viola kitaibeliana Roem. \& Schult. - Bács-Kiskun county, Tiszaug, east of the village, in saline grassland (2016) [9186.2].

Viola odorata L. - Pest county, Budakalász, frequent around the town (2016) [8380.3]; Pest county, Üröm, frequent around the settlement (2017) [8480.1].

Viola reichenbachiana Jord. - Budapest III, 'Mocsáros', in mesotrophic forests (2017) [8480.1]; Jász-Nagykun-Szolnok county, Tiszakürt, in the Tiszakürt Arboretum (2016) [9186.2]. 
Viola riviniana Rchb. - Pest county, Budakalász, Pilis Mts, 'Ezüst-Kevély', in acidofrequent oak forest (2017) [8380.3].

Viscum album L. - Budapest III, 'Ország út', under trees [8380.3]; Budapest XI, in the Buda Arboretum (2018) [8580.1].

Vulpia myuros (L.) C. C. Gmel. - Budapest III, Szentendrei út, 'Kaszásdűlö' suburban railway station, in fissures, few specimens (2018) [8480.1].

Waldsteinia geoides Willd. - Pest county, Nagykovácsi, Buda Mts, 'Remeteszurdok', in mesophilous forest, alongside the stream (2018) [8479.2]. The species does not have data from that grid cell, but SoMLYAY (2009) mentions several data from 'Remete-szurdok'.

Xeranthemum cylindraceum Sinth. \& Sm. - Pest county, Pilisborosjenő, Pilis Mts, 'Nagy-Kevély, near the copy of 'Egri vár', in grassland (2018) [8379.4].

\section{DISCUSSION}

Altogether 661 occurrence records for 497 taxa from 49 CEU grid cells are presented in this article. Most of the data presented in this article are well-known, but were never published or they are missing from the reference atlas of BARTHA et al. (2015), showing the deficiencies of this monographic work.

The utmost new records were found in grid cell 8480.1 (a part of Budapest III and Üröm), mainly because of two undermapped areas ('Mocsáros' and 'Rókahegy'), altogether 116 new taxa were found there. In the studied grid cells some wide-spread species are underrepresented in the atlas (e.g. Amaranthus powellii, Euphorbia maculata), in this paper there are 4-4 new localities presented for these species, the aimed mapping of these species could be rewarding. According to my records, the floristic mapping of some grid cells was incomplete, e.g. grid cell 8380.3 had only 414 taxa listed in BARTHA et al. (2015), but I present 86 new taxon records here, which is a $21 \%$ growth in taxon number in the grid cell. The distribution of new occurrence records is shown in Figure 1 and the number of new occurrence records per grid cell is shown in Figure 2.

New noteworthy native occurrence records are the second confirmed occurrence of Allium ursinum in the Pilis Mts, the confirmed occurrence of Ceratocephala testiculata in Budapest, where the plant survived in a rather transformed habitat, the two new localities for Astragalus asper, the two ruderal localities for Atriplex littoralis, the new occurrence record for Lindernia procumbens near Göd. The most interesting records for adventive plants are: Salvinia molesta in Dunaalmás, Physalis peruviana and Silybum marianum in Budapest, and Azolla filiculoides at Dunaszeg. 


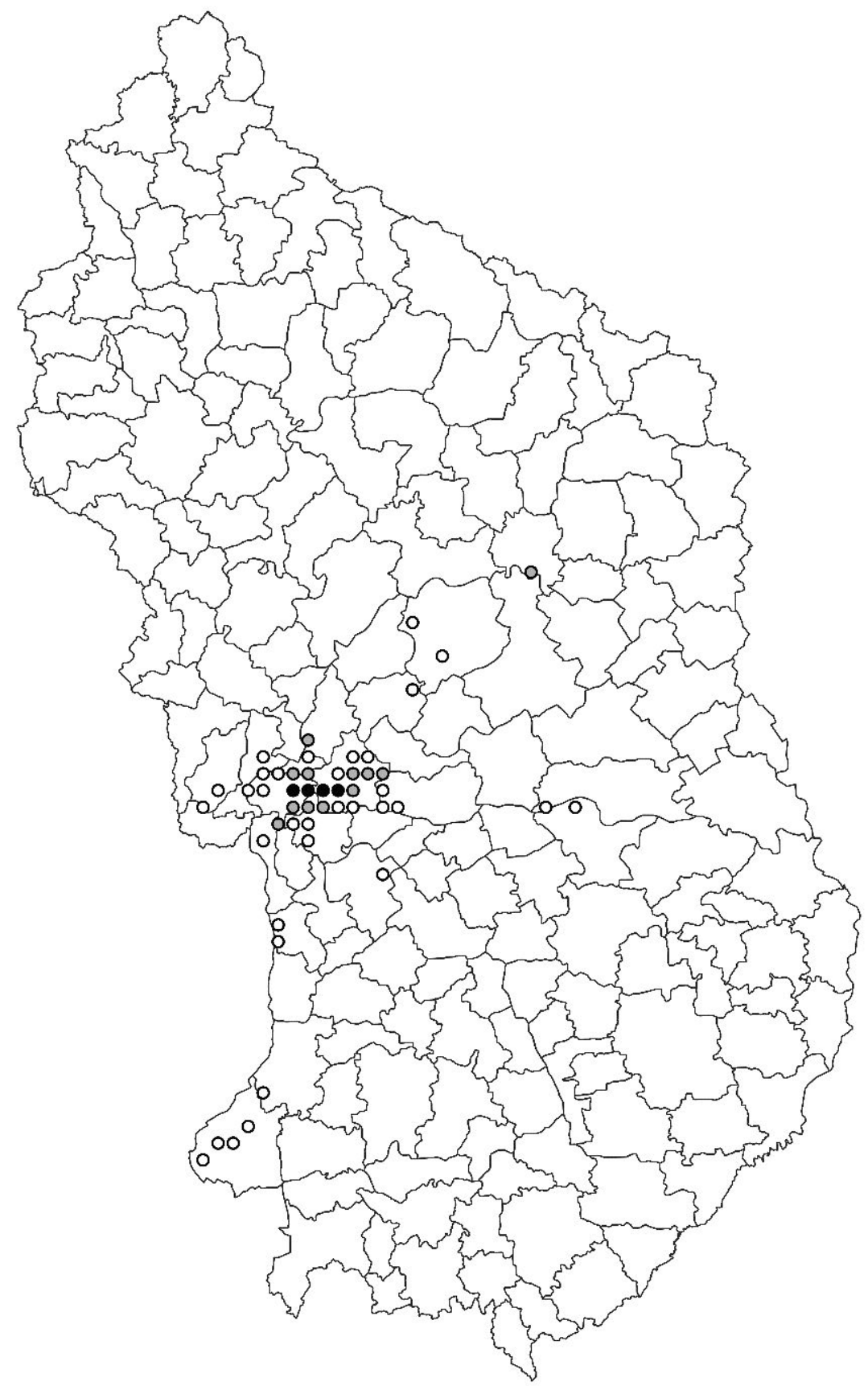

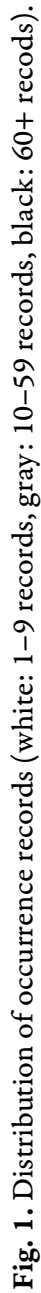




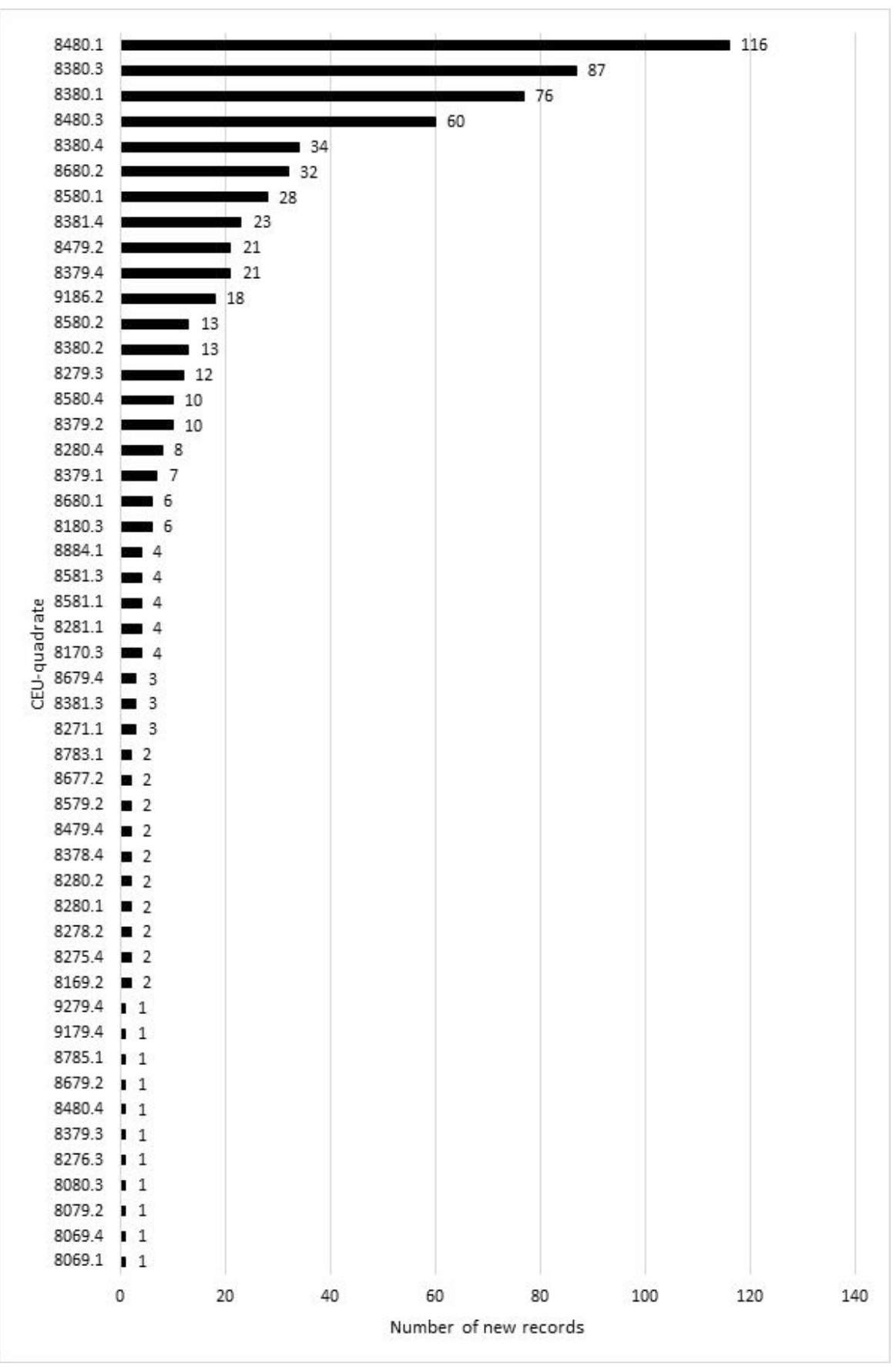

Fig. 2. Number of new records per CEU grid cell. 
Acknowledgements - I would like to thank László Máté Tálas for guiding me near Tiszakürt and Tiszaug and András Mártonffy for joining me on some field trips in the Buda Mts. I also would like to thank Zoltán Barina for his help in the determination of some taxa.

Összefoglaló: Ebben a cikkben a Magyarország edényes növényfajainak elterjedési atlaszához füzök kiegészítéseket. Összesen 497 taxon 661 elöfordulási adatát közlöm 49 KEF kvadrátból, főként Budapestről és környékéről, valamint a Duna és mellékfolyói mentéről. Említésre méltó az Allium ursinum második megerősített Pilisi előfordulása, a Pilis-tető északi oldalán, a Ceratocephala testiculata kis populációjának megtalálása a Villányi úton, ezzel a faj Budapesti előfordulásának megerősítése. Érdekesség továbbá az Atriplex littoralis két új lokalitása települések belterületén, utak mentén. Fontos adatok továbbá: az Astragalus asper két új előfordulása Soroksáron és Fóton, valamint a Lindernia procumbens előfordulása Gödnél, a Duna kiszáradt medrében. Az adventív előfordulások közül kiemelendö, a Salvinia molesta elöfordulása nagy tömegben egy dunaalmási kénes forrásban, a Physalis peruviana két előfordulása a budapesti Dunaparton, a Silybum marianum előfordulása Budán, illetve az Azolla filiculoides előforduása Dunaszegnél, szintén a Duna partján.

\section{REFERENCES}

BARINA Z. (2008): Adatok a Dunántúli-középhegység és környéke flórájához. - Flora Pannonica 6: $3-23$.

Barina Z., Benedek L., Boros L., Dima B., Folcz Á., Király G., Koszka A., Malatinszky Á., PAPp D., Pif Kó D. \& PAPP V. (2015): Taxonomical and chorological notes 1 (1-19). Studia bot. hung. 46(2): 205-221. https://doi.org/10.17110/StudBot.2015.46.2.205

Bartha D., Király G., Schmidt D., Tiborcz V., Barina Z., Csiky J., Jakab G., Lesku B., SChmotzer A., Vidéki R., Vojt kó A. \& Zólyomi Sz. (eds) (2015): Distribution atlas of vascular plants of Hungary. - University of West Hungary Press, Sopron, 329 pp.

Bogyáné [Bogya SÁndorné] \& KeCSKÉs F. (1993): A Soroksári Botanikus Kert "rezervátum" területének florisztikai vizsgálata. - A Kertészeti és Élelmiszeripari Egyetem Közleményei 53 (suppl.): 14-19.

Csiky J., Baráth K., Bocz V., Deme J., Fülöp Zs., Kovács D., Nagy K., Tamási B. \& Csikiné RADNAI É. (2017): Pótlások Magyarország edényes növényfajainak elterjedési atlaszához V - Kitaibelia 22(2): 383-403. https://doi.org/10.17542/kit.22.383

Csiky J., Baráth K., Csikiné Radnai É., Deme J., Wirth T., Zurdo J. A. \& Kovács D. (2018): Pótlások Magyarország edényes növényfajainak elterjedési atlaszához VIII. - Kitaibelia 23(2): 238-261. https://doi.org/10.17542/kit.23.238

Csiky J., Kováts D., Deme J., Takács A., Óvári M., Molnár V. A., Malatinszky Á., Nagy J. \& BARINA Z. (2017): Taxonomical and chorological notes 4 (38-58). - Studia bot. hung. 48(1): 133-144. https://doi.org/10.17110/StudBot.2017.48.1.133

KALAPOS T. \& SZERÉNYI J. (1997): A Magyarországról kipusztultnak vélt deres szádorgó (Orobanche caesia Rchb.) elöfordulása az érdi Sánc-hegyen. - Kitaibelia 2: 41-43.

KeCSKÉS F. \& KöвöLKUTi Z. A. (2016): Harasztok a Soroksári Botanikus Kertben. - In: HöHN M. \& PAPP V. (eds): Biodiverzitás a Soroksári Botanikus Kerben. Kriptogámok: gombák, zuzmók, mohák, harasztok - Magyar Biodiverzitás-kutató társaság \& SZIE Kertészettudományi Kar, Soroksári Botanikus Kert, Budapest, pp. 151-164.

Kevey B. (1978): Az Allium ursinum L. magyarországi elterjedése. - Bot. Közlem. 65(3): 165-175. 
Kevey B. (2017): Pótlások Magyarország edényes növényfajainak elterjedési atlaszához IV. Kitaibelia 22(2): 358-382. https://doi.org/10.17542/kit.22.358

Kevey B. (2018): Pótlások Magyarország edényes növényfajainak elterjedési atlaszához VII. Kitaibelia 23(2): 218-237. https://doi.org/10.17542/kit.23.218

Király G. (ed.) (2009): Új Magyar füvészkönyv. Magyarország hajtásos növényei. Határozókulcsok. - Aggteleki Nemzeti Park Igazgatóság, Jósvafö, 616 pp.

Király G., Balogh L., Barina Z., Bartha D., Bauer N., Bodonczi L., Dancza I., Farkas S., Galambos I., Gulyás G., Molnár V. A., Nagy J., Pifkó D., Schmotzer A., Somlyay L., Szmorad F., Vidéki R., Vojt Kó A. \& Zólyomi Sz. (2003): A magyarországi flóratérképezés módszertani alapjai. Útmutató és magyarázat a hálótérképezési adatlapok használatához. - Flora Pannonica 1(1): 3-20.

Korda M., VIDÉKI R. \& DANYI K T. (2008): Az amerikai rucaöröm (Salvinia molesta D. S. Mitchell) és a sallangos vízipáfrány (Ceratopteris thalictroides (L.) Brongn.) Magyarországon. - Kitaibelia 13(1): 171.

Matus G., Csiky J., Bauer N., Baráth K., Vasuta G., Barabás A, Hricsovinyi D., Takács A., Antal K., Budai J., Erzberger P., Molnár P. \& Barina Z. (2018): Taxonomical and chorological notes 7 (75-84). - Studia bot. hung. 49(2): 83-94.

https://doi.org/10.17110/StudBot.2018.49.2.83

Mesterházy A., Matus G., Király G., Szücs P., Török P., Valkó O., Pelles G., Papp V. G., ViróK V., NemcsoK Z., Rigó A., Hohla M. \& Barina Z. (2017): Taxonomical and chorological notes 5 (59-70). - Studia bot. hung. 48(2): 263-275.

https://doi.org/10.17110/StudBot.2017.48.2.263

Molnár Cs., Haszonits Gy., Malatinszky Á., Kovács G. K., Kovács G., Nagy T., Molnár V. A. \& TAKÁcs A. (2017): Pótlások Magyarország edényes növényfajainak elterjedési atlaszához III. - Kitaibelia 22(1): 122-146. https://doi.org/10.17542/kit.22.122

Molnár Cs., Haszonits Gy., Malatinszky Á., Süveges K., Balogh L., Nagy T., Horváth S. \& HUDÁK K. (2018): Pótlások Magyarország edényes növényfajainak elterjedési atlaszához VI. - Kitaibelia 23(1): 87-102. https://doi.org/10.17542/kit.23.87

Molnár Cs., Lengyel A., Molnár V. A., Nagy T., Csábi M., Süveges K., Lengyel-Vaskor D., Tóth Gy. \& TAKÁcs A. (2016): Pótlások Magyarország edényes növényfajainak elterjedési atlaszához II. - Kitaibelia 21(2): 227-252. https://doi.org/10.17542/kit.21.227

NAGY J. (2007): A Börzsöny hegység edényes flórája. - Duna-Ipoly Nemzeti Park Igazgatósága, Budapest, $378 \mathrm{pp}$.

Papp V., Király G., Koscsó J., Malatinszky Á., Nagy T., Takács A. \& Dima B. (2016): Taxonomical and chorological notes 2. - Studia bot. hung. 47(1): 179-191. https://doi.org/10.17110/StudBot.2016.47.1.179

SCнмidT D. (2013): Néhány érdekesebb növényfaj megjelenése a Duna 2013. évi nagy árvize után a Szigetköz hullámterében. - Kitaibelia 20(2): 303-304. https://doi.org/10.17542/kit.20.300

Schmidt D., Csiky J., Matus G., Balogh R., Szurdoki E., Höhn M., Ábrán P., BuczKó K. \& Löкӧs L. (2018): Taxonomical and chorological notes 6 (71-74). - Studia bot. hung. 49(1): 121-130. https://doi.org/10.17110/StudBot.2018.49.1.121

SomLyay L. (2009): A Budai-hegység florisztikai növényföldrajzának fő vonásai. - Kitaibelia $14(1): 35-68$.

SomLYAY L., MAKÁDi S. \& CsÁbi M. (2016): Adatok Budapest környéke flórájának ismeretéhez II. - Kitaibelia 21(1): 33-50. https://doi.org/10.17542/kit.21.33

Takács A., Baráth K., Csiky J., Csikyné R. É., Király G., Nagy T., Papp V., Schmidt D., TAMÁsi B. \& BARINA Z. (2016): Taxonomical and chorological notes 3 (28-37). - Studia bot. hung. 47(2): 345-357. https://doi.org/10.17110/StudBot.2016.47.2.345 
Takács A., Nagy T., Sramkó G., Lovas-Kiss Á., Süveges K., LukÁcs B. A., Fekete R., LöKi V., Malatinszky Á., E. Vojt kó A., Koscsó J., Pfliegler W. P., Nótári K. \& Molnár V. A. (2016): Pótlások a Magyarország edényes növényfajainak elterjedési atlaszához I. Kitaibelia 21 (1): 101-115. https://doi.org/10.17542/kit.21.101

(c) OpenStreetMap contributors: OpenStreetMap - openstreetmap.org - the data is available under the Open Database License, the cartography is licensed as CC BY-SA. (accessed online 25.03.2019).

The Plant List (2013): Version 1.1. Published on the Internet; http://www.theplantlist.org/ (accessed: 06.04.2019).

(submitted: 06.04.2019, accepted: 18.05.2019) 